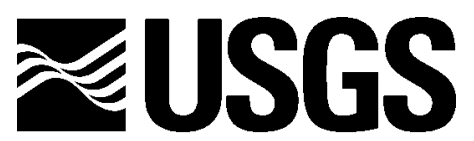

science for a changing world

In Cooperation with the World Bank, the Mauritania Ministry of Mines and Industry, and Futures Group

\title{
Inventory and Review of Existing PRISM Hydrogeologic Data for the Islamic Republic of Mauritania, Africa
}

By Michael J. Friedel

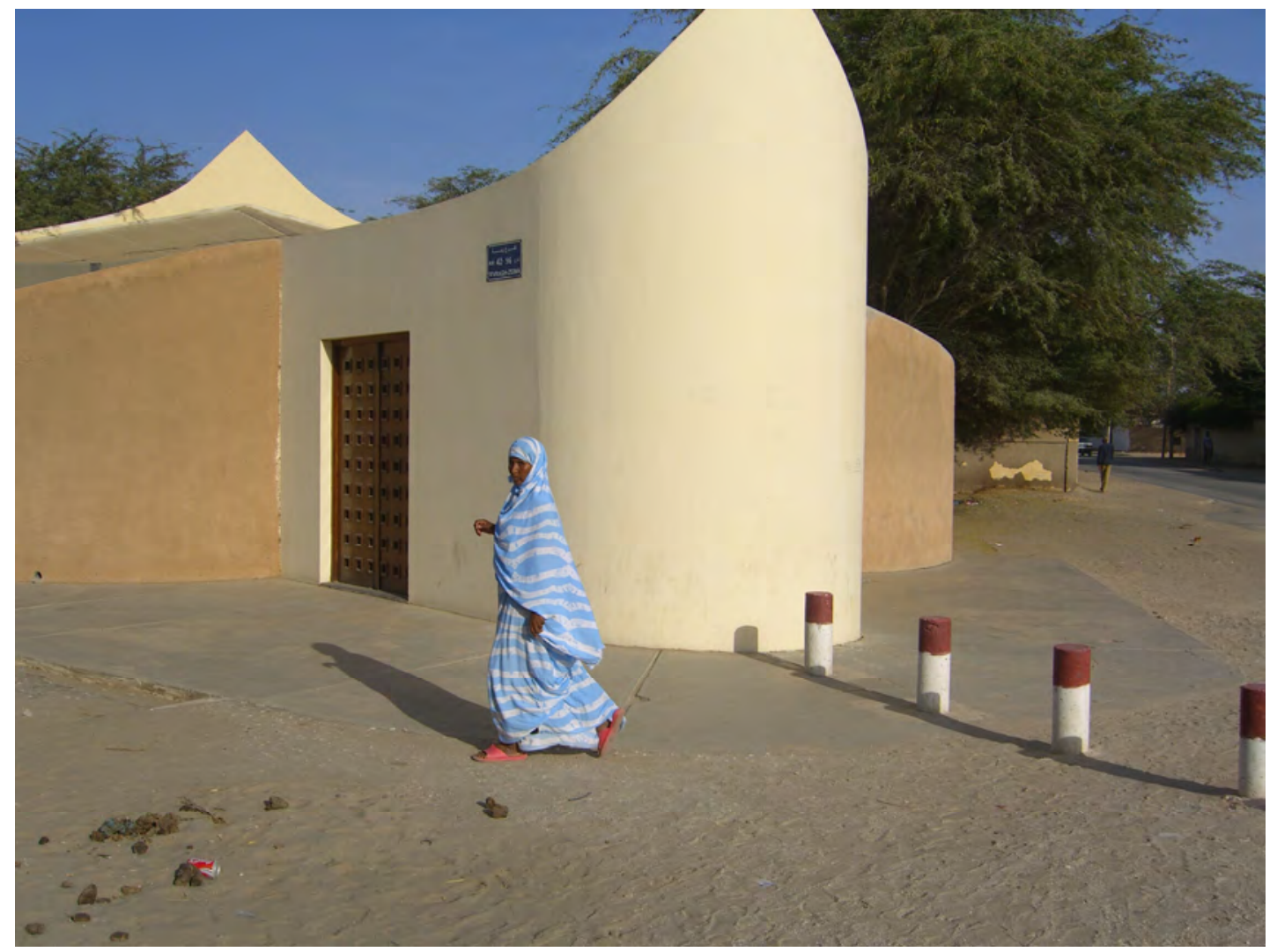

Open-File Report 2008-1138

U.S. Department of the Interior

U.S. Geological Survey 


\section{U.S. Department of the Interior DIRK KEMPTHORNE, Secretary}

\section{U.S. Geological Survey \\ Mark D. Myers, Director}

U.S. Geological Survey, Reston, Virginia 2008

For product and ordering information:

World Wide Web: http://www.usgs.gov/pubprod

Telephone: 1-888-ASK-USGS

For more information on the USGS - the Federal source for science about the Earth, its natural and living resources, natural hazards, and the environment:

World Wide Web: http://www.usgs.gov

Telephone: 1-888-ASK-USGS

Suggested citation:

Friedel, M.J., 2008, Inventory and review of existing PRISM hydrogeologic data for the Islamic Republic of Mauritania, Africa: U.S. Geological Survey, Open-File Report 2008-1138. 69 p.

Any use of trade, product, or firm names is for descriptive purposes only and does not imply endorsement by the U.S. Government. 


\section{Contents}

Abstract

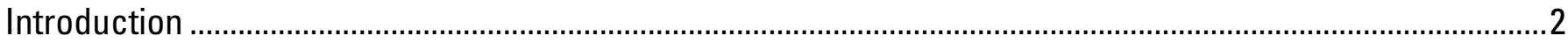

Inventory of Hydrogeologic Information ……………………..............................................................

Reports of Choum-Zouerate …………......................................................................................................

GIS, Excel, and Document Files of Mauritania …………..............................................................................

Relational Database of Choum-Zouerate and Mauritania …….......................................................................

Review of Hydrogeologic Information ........................................................................................................

Reports

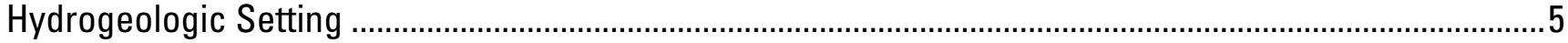

Evaporation, Evapotranspiration, and Precipitation ……………………………………………….....

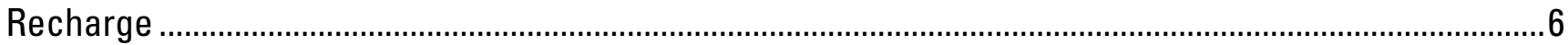

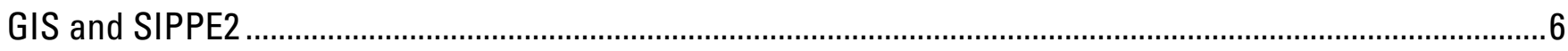

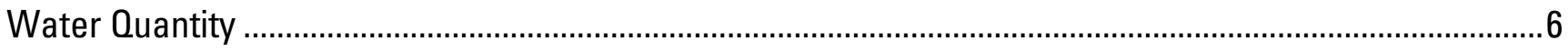

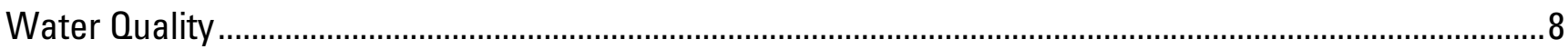

Summary and Conclusions ........................................................................................................................

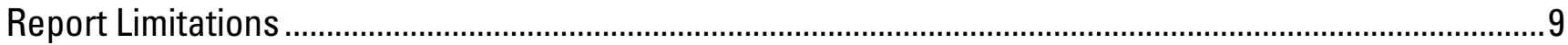

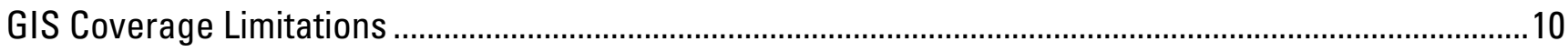

SIPPE2 Database Limitations.................................................................................................................

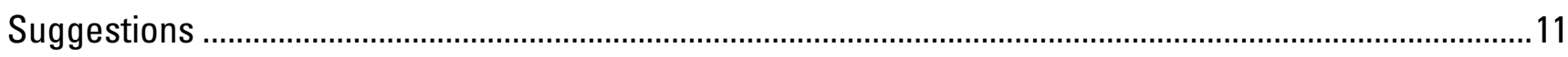

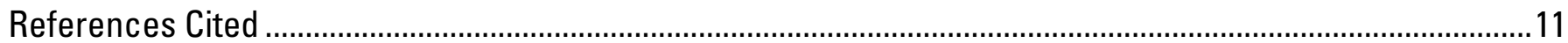

\section{Figures}

1. Schematic of relational tables in SIPPE2 Access database...................................................................13

2. Relief, streams, sebkhas, and lakes...................................................................................................14

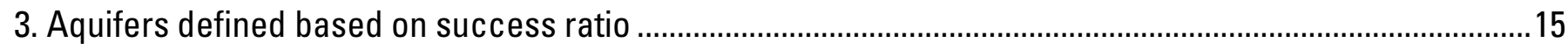


4. Distribution of hydraulic head values provided as GIS coverages .............................................................16

5. Distribution of measured water levels from the SIPPE2 database ..............................................................17

6. Distribution of aquifer transmissivity from the SIPPE2 database ..................................................................18

7. Distribution of dissolved nitrate in groundwater from the SIPPE2 database ...............................................19

8. Distribution of dissolved bicarbonate in groundwater from the SIPPE2 database .........................................20

9. Distribution of dissolved sodium in groundwater from the SIPPE2 database ................................................21

10. Distribution of dissolved oxygen in groundwater from the SIPPE2 database..............................................22

11. Distribution of electrical conductivity in groundwater from the SIPPE2 database........................................23

\section{Tables}

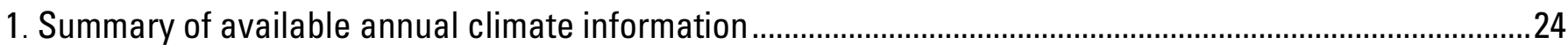

2. Annual evaporation, evapotranspiration, and humidity measurements .........................................................24

3. Summary of evaporation at measurement stations across Mauritania............................................................25

4. Summary of groundwater physical parameter and chemical concentrations from SIPPE2 database........26

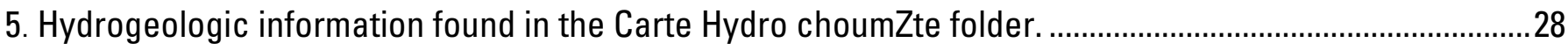

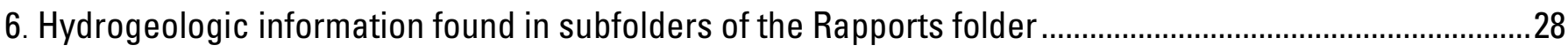

7. Hydrogeologic information (PRISM-2) found in subfolders of the SIPPE2 folder............................................30

8. Hydrogeologic information found in subfolders of the Hydrology folder ......................................................

9. Hydrogeologic information found in subfolders of the SIGE folder............................................................3

10. Overview of tables and fields found in the SIPPE2 database ………........................................................

11. Hydrogeologic inventory of aquifer area, thickness, and volume .............................................................40

12. Hydrogeologic inventory of production, porosity, and hit ratio ..................................................................4

13. Hydrogeologic inventory of instantaneous flows and associated salinity concentrations...........................46

14. Hydrogeologic inventory of hydraulic properties .....................................................................................4

15. Hydrogeologic inventory of piezometric head map and recharge potential ................................................52 


\section{Appendix Files}

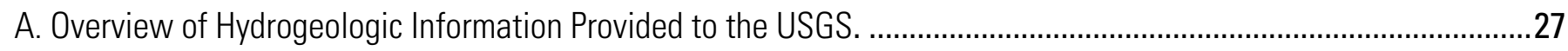

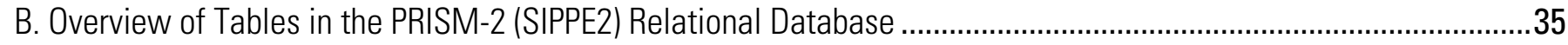

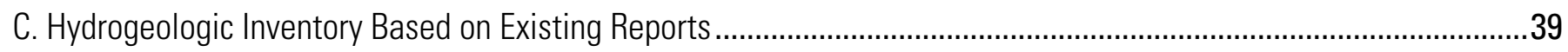

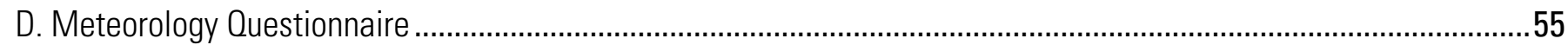

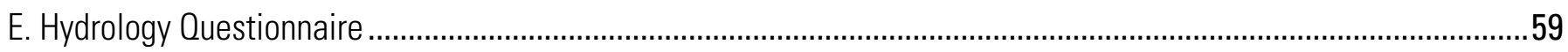

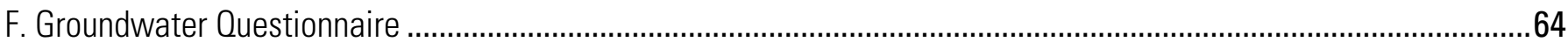




\section{Conversion Factors}

\section{Inch/Pound to SI}

\begin{tabular}{lll}
\hline Multiply & By & To obtain \\
\hline Length & & \\
\hline foot (ft) & 0.3048 & meter $(\mathrm{m})$ \\
mile (mi) & 1.609 & kilometer $(\mathrm{km})$ \\
yard (yd) & 0.9144 & meter $(\mathrm{m})$ \\
\hline Volume & & \\
\hline ounce, fluid (fl. oz) & 0.02957 & liter $(\mathrm{L})$ \\
gallon (gal) & 0.003785 & cubic meter $\left(\mathrm{m}^{3}\right)$ \\
cubic inch (in $\left.{ }^{3}\right)$ & 0.01639 & liter $(\mathrm{L})$ \\
cubic foot $\left(\mathrm{ft}^{3}\right)$ & 0.02832 & cubic meter $\left(\mathrm{m}^{3}\right)$ \\
\hline Flow rate & & \\
\hline foot per second (ft/s) & 0.3048 & meter per second $(\mathrm{m} / \mathrm{s})$ \\
cubic foot per second $\left(\mathrm{ft}^{3} / \mathrm{s}\right)$ & 0.02832 & cubic meter per second $\left(\mathrm{m}^{3} / \mathrm{s}\right)$ \\
\hline Mass & & \\
\hline ounce, avoirdupois $(\mathrm{oz})$ & 28.35 & gram $(\mathrm{g})$ \\
pound, avoirdupois $(\mathrm{lb})$ & 0.4536 & kilogram $(\mathrm{kg})$ \\
\hline
\end{tabular}

Temperature in degrees Fahrenheit $\left({ }^{\circ} \mathrm{F}\right)$ may be converted to degrees Celsius $\left({ }^{\circ} \mathrm{C}\right)$ as follows: ${ }^{\circ} \mathrm{C}=\left({ }^{\circ} \mathrm{F}-32\right) / 1.8$ 


\section{SI to Inch/Pound}

\begin{tabular}{lcl}
\hline Multiply & By & To obtain \\
\hline Length & & \\
\hline meter $(\mathrm{m})$ & 3.281 & foot $(\mathrm{ft})$ \\
kilometer $(\mathrm{km})$ & 0.6214 & mile $(\mathrm{mi})$ \\
meter $(\mathrm{m})$ & 1.094 & yard $(\mathrm{yd})$ \\
\hline Volume & & \\
\hline liter $(\mathrm{L})$ & 0.2642 & gallon $(\mathrm{gal})$ \\
cubic meter $\left(\mathrm{m}^{3}\right)$ & 264.2 & gallon $(\mathrm{gal})$ \\
liter $(\mathrm{L})$ & 61.02 & cubic inch $\left(\mathrm{in}^{3}\right)$ \\
cubic meter $\left(\mathrm{m}^{3}\right)$ & 35.31 & cubic foot $\left(\mathrm{ft}^{3}\right)$ \\
\hline Flow rate & & \\
\hline meter per second $(\mathrm{m} / \mathrm{s})$ & 3.281 & foot per second $(\mathrm{ft} / \mathrm{s})$ \\
cubic meter per second $\left(\mathrm{m}^{3} / \mathrm{s}\right)$ & 35.31 & cubic foot per second $\left(\mathrm{ft}^{3} / \mathrm{s}\right)$ \\
\hline Mass & & \\
\hline gram $(\mathrm{g})$ & 0.03527 & ounce, avoirdupois $(\mathrm{oz})$ \\
kilogram $(\mathrm{kg})$ & 2.205 & pound avoirdupois $(\mathrm{lb})$ \\
\hline
\end{tabular}

Temperature in degrees Celsius $\left({ }^{\circ} \mathrm{C}\right)$ may be converted to degrees Fahrenheit $\left({ }^{\circ} \mathrm{F}\right)$ as follows:

${ }^{\circ} \mathrm{F}=\left(1.8 \mathrm{x}^{\circ} \mathrm{C}\right)+32$ 


\title{
Inventory and Review of Existing PRISM
}

\section{Hydrogeologic Data for the Islamic Republic of Mauritania, Africa}

By Michael J. Friedel

\begin{abstract}
The USGS entered into an agreement with the Mauritania Ministry of Mines and Industry to inventory and review the quality of information collected as part of the Project for Strengthening of the Institutions in the Mining Sector (PRISM). Whereas the PRISM program collected geophysical, geochemical, geological, satellite, and hydrogeologic information, this report focuses on an inventory and review of available hydrogeologic data provided to the USGS in multiple folders, files, and formats. Most of the information pertained to the hydrogeologic setting and the water budget of evaporation, evapotranspiration, and precipitation in the Choum-Zouerate area in northwestern Mauritania, and the country of Mauritania itself. Other information about the quantity and quality of groundwater was found in the relational Access database. In its present form, the limited hydrogeologic information was not amenable to conducting water balance, geostatistical, and localized numerical modeling studies in support of mineral exploration and development. Suggestions are provided to remedy many of the data's shortcomings, such as performing quality assurance on all SIPPE2 data tables and sending questionnaires to appropriate agencies, mining and other companies to populate the database with additional meteorology, hydrology, and groundwater data.
\end{abstract}




\section{Introduction}

In 1996, the Islamic Republic of Mauritania requested that the U.S. Geological Survey (USGS) develop a strategic plan for the acquisition, improvement, and modernization of multidisciplinary sets of data to support the growth of the minerals sector and highlight mineral exploration potential of the country. Since development of that plan, the Ministry for Mines and Industry implemented the Project for Strengthening of the Institutions in the Mining Sector (PRISM) in which earth science information was acquired through financing from the World Bank, the Islamic Bank of Development, French cooperation, and the government of Mauritania (British Geological Survey, 1996). As a result of these efforts, new geological, geophysical, geochemical, hydrogeologic, and remote sensing data were provided to evaluate areas favorable to mineral exploration and development in Mauritania.

To benefit from the aggregation of new and existing data, the Mauritanian Mines and Industry called for proposals from the international geoscience community for a second project phase (PRISM-2) to synthesize and prepare these data to promote the mining sector. As part of the PRISM-2 project, the USGS agreed to provide the Mauritania Ministry of Mines and Industry with an inventory and review of their data. This first phase acquired data produced by the original PRISM study, as well as existing maps, documents, and other data on the mineral resource potential of Mauritania. This report provides an inventory and review of a subset of these data with emphasis on the available PRISM hydrogeological information (databases and related files).

Inventory and evaluation of the PRISM hydrogeologic information was conducted with four modeling components in mind: conceptualization, parameterization, boundary conditions, and calibration constraints. Conceptualization of a numerical model requires constructing data sets that describe all aspects of the groundwater system; for example, the geometry (thickness and area) of aquifers and confining units, and the location and types of boundary conditions. Parameterization involves assigning parameter values that control the flux rate of movement within the simulated groundwater basin. Examples of groundwater flow parameters include hydraulic conductivity, transmissivity, storativity (or storage coefficient), and porosity. In addition, arid regions such as Mauritania also have a comparatively large variably-saturated zone between the surface and the water table. Such a zone can include features such as dunes or alluvium in the ephemeral streams (oeuds or wadis). Whereas hydraulic parameters such as saturated hydraulic conductivity and various retention properties are easily obtainable for porous material, this information is not readily 
available for fractured rock systems. Likewise, some boundary conditions (system stresses) such as precipitation, recharge, and streamflow discharge are not easily quantifiable. Other necessary information on boundary conditions include pumping, evaporation, and evapotranspiration. In many cases, either parameter values or some boundary conditions or both are not available. In these cases, their values need to be estimated using an objective inverse procedure (called model calibration or parameter estimation) that provides consistency with observed field measurements. These field measurements constrain the solution space; hence, they are called calibration constraints. Calibration constraints can include any combination of model-dependent variables, such as water levels, hydraulic head values, recharge rates, and evapotranspiration rates. In coupled mass and energy models, temperature and concentration values are often included in the estimation of related parameters. The following sections describe the findings of the hydrogeologic inventory and review.

\section{Inventory of Hydrogeologic Information}

The hydrogeologic information was provided to the USGS in multiple folders, files, and formats, in two groupings that pertained to the Choum-Zouerate area in northwestern Mauritania, and the country of Mauritania itself. A complete list of the folders (bolded), subfolders, files, and brief descriptions are provided in Appendix A.

\section{Reports of Choum-Zouerate}

Information pertaining to Choum-Zouerate are in the form of various reports and an Access database called SIPPE2. In the Carte Hydro choumZte folder (table 5), various reports provide overviews of the hydrogeology and the numerical modeling of the Zouerate area to understand the influence of mining, drilling, the regional management, the terrain, and the satellite imaging. All reports were originally published in French.

In the Rapports folder (table 6), a report describes the SIPPE2 (PRISM-2) database installation and use of the management graphical user interface. The executable files associated with the SIPPE2 database are found in the SIPPE2 folder. The SIPPE2 database has a management interface that was not operational because the required username and password were not provided to the USGS. Because of this, queries were set up and run to organize and retrieve data through the SIPPE2 Access database, called Tables_SIPPE2.mdb. 


\section{GIS, Excel, and Document Files of Mauritania}

Hydrogeologic information for Mauritania was available as graphical information system (GIS in ArcView format), spreadsheet (EXCEL format), and document (WORD and PDF formats) files in the Notice Hydrogeol folder. Some of this information provides an overview of formations, groups, and geology at 1:200,000, 1:500,000, and 1:1,000,000 scales for the management areas of Hank, Zerma, Adrar, Tagant, Assaba, Affole, and Hodh. Information on drilling results are provided in a spreadsheet, with individual pages describing drilling in specific groups or areas. A limited number of well studies are provided by area (Tijirit Amsaga, Reguibat LB, Imourène Sougy Delpy LB, and Bir Moghrein TECSULT). Another well study of the AOUKER area is summarized in a separate Excel file. The last study summarized in Excel format provides an overview of drilling activities in the Tijirit, Zemmour, Noir, Amsaga, and Tiris areas. A complementary document file provides an overview by region of the economic activities, climate, and geology.

\section{Relational Database of Choum-Zouerate and Mauritania}

As part of PRISM-2, a Microsoft Access ${ }^{\circledR}$ relational database called SIPPE2 was developed and includes 30 related tables and files (fig. 1). In this database, PE and SNIM prefixes pertain to drilling, testing, and sampling across Mauritania and the Choum-Zouerate area, respectively. The most important data table is called PE_PointDEau (water point) and has 11,235 records. Using these primary tables, the primary keys were linked to other tables and queries were run to extract, summarize, and evaluate various sets of hydrogeologic information accordingly. The following section provides a summary of findings for the available GIS and SIPPE2 database information.

\section{Review of Hydrogeologic Information}

The overview of hydrogeologic information is in three sections: reports, GIS, and SIPPE2 database. Key information found in the reports includes hydrogeologic setting and the water budget components of evaporation, evapotranspiration, and precipitation. Other information about water quantity and quality are found in the relational database. 


\section{Reports}

\section{Hydrogeologic Setting}

The country of Mauritania is $1,030,700 \mathrm{~km}^{2}$, and is bounded by the Atlantic Ocean to the west, the Senegal River to the south, and the respective countries of Western Sahara, Algeria, and Mali to the northwest, north, and east. Elevation begins at sea level and rises to about $400 \mathrm{~m}$. The primary rivers include the Senegal along the Senegal border, the Gorgol in the Tagant area, the Garfa and Niorda in the Assaba area, and the Karakoro along the Mali border (fig. 2). With the exception of the Senegal River, all of the rivers are ephemeral. Whereas the Senegal River used to be ephemeral, the river is now artificially maintained in a perennial state through releases of water at an upstream reservoir located in Mali. In addition to these primary rivers, there are wadis, which are smaller ephemeral tributary rivers that include: Seguelil from Atar at the confluence on plandis of Adrar and Amsaga; El Abiod from the south; Khatt depression between Adrar and Tagant; and Tayaret, which is hundreds of kilometers long and is purported to be the oldest stream network, dating back to the Holocene. There are two primary lakes and numerous sebkhas (ephemeral lakes), such as Lake Aleg, which receives water from the Ketchi wadi, and Lake R'Kiz, which receives water by the Senega River. There was no information provided on the locations of stream gage stations and/or streamflow discharge measurements (at any frequency) in any of the reports, GIS files, or databases.

\section{Evaporation, Evapotranspiration, and Precipitation}

Climate-related hydrogeologic water budget components found in various reports include evaporation, evapotranspiration, and precipitation. The combination of wind, humidity, temperature, and sun angle all contribute to the magnitude of evaporation. The climate of Mauritania is arid and hot, with annual minimum and maximum temperatures of $19.2^{\circ} \mathrm{C}$ and $36.9^{\circ} \mathrm{C}$, respectively (table 1). Whereas the prevailing wind direction of northeast was given, there is no temporal or spatial information provided for local wind direction, magnitude, or humidity. Annual values of evaporation also were reported for various stations across Mauritania (tables 2-3), and values of evapotranspiration were computed for these stations using the Pennman equation.

More than 60 years of records at a limited number of stations were used to compute annual precipitation (rainfall) values. These data were sufficient to indicate a climatic shift beginning in about 1970, with an annual decrease in precipitation of $100 \mathrm{~mm}$, but were inappropriate for 
numerical modeling of places where the rainfall intensity varies spatially and temporally. For example, $54 \%$ of the annual rainfall for any given location in Mauritania can fall in as little as an hour. Other than the annual minimum and maximum climatic values described, no other available data sets were sampled more frequently or at additional sites.

\section{Recharge}

A third water budget component not directly discussed in the reports is ground-water recharge. The first two components, evaporation and precipitation, directly affect the ability of infiltrating water to become available to the groundwater system as recharge. The climatic shift and the extreme temporal and spatial variability in rainfall in Mauritania should have a profound affect on infiltration and therefore on ground-water recharge. Although lakes, wadis, and the artificial perennial streamflow of the Senegal River have the potential to provide recharge to the groundwater system, ground-water recharge in Mauritania has not been directly quantified (see comments in Appendix C). The only available reference quantifying recharge was an indirect estimation on an international scale by Ould and others (2006). Because the spatial and temporal magnitude of ground-water recharge is unknown, Bertone and others (2006) evaluated, as part of PRISM-2, the likely effect (sensitivity) of various hypothetical recharge scenarios on hydraulic head values in the Choum-Zouerate area, given certain mining operational conditions. One conclusion is that because so much uncertainty exists in the recharge boundary condition, future studies need to focus on quantifying recharge associated with dunes and wadis.

\section{GIS and SIPPE2 Database}

\section{Water Quantity}

Several direct and indirect methods can be used to estimate the quantity of ground-water recharge. One approach is to assume that the net change in storage is zero (mass budget, where inflows - outflow $=0$ ). In many cases, this steady-state assumption can be used if the water balance components can be determined and are stationary (that is, the mean values do not change over time). The ability to quantify a water budget using a direct (or indirect model calibration) approach is dependent on three criteria: the conceptualization of the model (aquifer description), the supplied values of model parameters (parameterization), and boundary conditions (system stresses). To evaluate the ability to meet these criteria, relevant information from reports, spreadsheets, and the 
SIPPE 2 database was tabulated. Specific hydrogeologic information that was aggregated included conceptualization: area, thickness, volume, productive zone, porosity, volume of water, and hit ratio; hydraulic parameters: permeability, transmissivity, and storativity; boundary conditions: production, potentiometric head values, instantaneous flows, and salinity (Appendix C).

Reviewing these tables reveals insufficient information about aquifer area and thickness to allow us to devise a traditional conceptual model. The most consistent sets of information are the hit ratio and instantaneous flows, which are interpreted as the success for producing water and the flow rate, respectively. Descriptions in several reports underscore that all but the southern Continental Terminal aquifer are characterized as fractured and/or karstic with little primary porosity and no correlation to aquifer thickness. These findings, in conjunction with the assertion by Bertone and others (2006) that pump tests are characterized by radial flow through the fractured rock, supports the notion of local equivalent porous media. With this in mind, the range of hit ratios may be viewed as a relative descriptor of heterogeneity (fracture density) in a single aquifer overlying a single impermeable base (fig. 3). In this case, the layer overlying the impermeable base might best be considered stochastic within aquifers or heterogeneous zones. The hydraulic parameters, such as transmissivity and storativity, can be described as random variables, possibly with some correlation to hit ratio and/or instantaneous flows (see table 4).

Whereas it may be possible to provide stochastic rainfall amounts at various locations using a regional downscaling approach, there are no data available on pumping or injection of wells. Several known well fields along the Atlantic coast, in the southern part of the country, and north of the Senegal River are used for public water supply; however, there do not appear to be any associated time-series pumping records in the SIPPE2 database. Historical pumping records for any mining activities also are lacking. The GIS coverages provided for potentiometric head values reveal cones of depression that presumably are located at primary pumping centers (fig. 2c). It is not clear, however, whether these data represent a synoptic study or are simply measurements collected at various times. In the SIPPE2 database, much of the water level data are associated with different years. Where these data indicate changes in water levels (fig. 2d), there is no elevation information provided from which to convert these values to values of hydraulic head.

One suggestion is to populate the SIPPE2 database with well-head elevation information in order to convert the water level data to hydraulic head values. In addition, the head values used to produce the potentiometric maps need to be included in the SIPPE2 database. This information would result in a more complete map (for example, adding missing values to the aquifer described 
by the $45-65 \%$ hit ratio in south-central Mauritania, fig. 3). Additionally, a series of time-based head maps could be produced for interpreting the direction of groundwater flow, computing boundary fluxes (groundwater inflows and outflows), determining changes in storage, and constraining the calibration of any future numerical models. Other missing information includes the 624 water points (495 static water-level measurements from boreholes, dug wells, and oases) that were recorded and used in the Choum-Zouerate modeling study. After reviewing figures 3-11, we find the primary spatial deficiency in hydrogeologic measurements is in the central and east-central regions of Mauritania, where no information exists. Likewise, there are no physical measurements of infiltration, streamflow discharge, or saturated or unsaturated hydraulic information associated with wadis, sebkhas, or dunes. Anecdotal information provided in the reports indicates that water levels fluctuate both seasonally and following rain events below sebkhas, and in dug wells, domestic wells, and boreholes. More information from these regions would help calculate a more accurate water budget accounting (especially to determine groundwater recharge and sustainability) and as constraint information in numerical modeling studies.

\section{Water Quality}

As described in the companion calibration strategy report (Friedel, 2008), multiple types of measurements are required to facilitate convergence and minimize model uncertainty. Whereas flow modeling would ideally include constraint measurements such as head and flux measurements (ground-water, evaporative, and recharge), transport modeling requires additional water-quality information to constrain the estimation of transport parameters. Presently, a limited number of water-quality measurements of concentrations and aqueous physical characteristics are available in the SIPPE2 database. A summary of selected water-quality data $\left(\mathrm{Ca}^{2+}, \mathrm{HCO}_{3}{ }^{-}, \mathrm{Na}^{+}, \mathrm{NO}_{3}{ }^{-}, \mathrm{SO}_{4}{ }^{2-}\right.$, dissolved oxygen, electrical conductivity, $\mathrm{pH}$, and temperature) are provided in table 4 and as maps (figs. 6-10), all revealing their limited spatial distribution. GIS coverages (not shown here) of salinity (total dry residue) are available for the same areas.

While evaluating the SIPPE2 database, several issues came to light. First, there is too much variability in the amount, time, and location of water-quality information sampled (see table 4 and fig. 2). There are also quality assurance problems in which duplicate records and physically implausible values appear. For example, prior to removing outliers, there were impossible numerical ranges, such as those for $\mathrm{pH}: 0.8$ - 737.3, conductivity: 6 - $67000 \mathrm{uS} / \mathrm{cm}$, temperature: $3.5-32532.5{ }^{\circ} \mathrm{C}$, and static water level: $2.5-121 \mathrm{~m}$. Finally, no redox (pe or speciation pairs such 
as for iron, manganese, or arsenic), dissolved inorganic carbon (DIC), or isotopic measurements are available. Water isotopes are useful in conceptualizing the system hydraulics, whereas carbon isotopes and DIC can be used as model input to NETPATH for estimating the age of water between the present and tens of thousands of years ago. This information could confirm fossil gradients and test the hypothesis of Holocene recharge of the Mauritanian aquifers (Bertone and others, 2006). Other isotopic tracers such as tritium and helium could be used with water isotopes $\left({ }^{18} \mathrm{O} \delta\right.$ and deuterium) and dissolved gases to understand the role of sebkhas, wadis, and dunes in recharging and discharging the groundwater system. In addition to refining the conceptual model, this information can also constrain future numerical models.

\section{Summary and Conclusions}

In 2006, the USGS entered into an agreement with the Mauritania Ministry of Mines and Industry to inventory and evaluate the quality of their PRISM data sets. These data sets were collected by outside contractors through financing from the World Bank, the Islamic Bank of Development, French cooperation, and the government of Mauritania in support of mineral exploration and development in Mauritania. Whereas the PRISM program involved collection of geophysical, geochemical, geological, satellite, and hydrological data sets, this report focuses only on assessing the quantity and quality of available hydrogeological data. The general finding is that, in the present form, the quantity and quality of the hydrogeologic data are limited in the ability to conduct water balance, geostatistical, and localized numerical modeling studies in support of mineral exploration and development. One or more of these issues may be remedied if the following data issues can be resolved.

\section{Report Limitations}

- There are no humidity measurements in reports or the SIPPE 2 data tables.

- There is no information on depth and areal extent of aquifers.

- There are no stage measurements for lakes, sebkhas, or wadis.

- There is no information on domestic, industrial, or mining pumping rates.

- There is no information on domestic, industrial, or mining pumping center locations.

- There is no information on recharge rates. 
- There is no measured dissolved inorganic carbon or dissolved organic carbon.

- There is no measured redox potential (pe) or speciation pairs, iron, manganese, or arsenic.

- There are no measured isotopes.

- There are no water-level measurements associated with the wadis or sebkhas.

- There are no measurements of infiltration or discharge associated with the wadis or sebkhas.

\section{GIS Coverages Limitations}

- The available potentiometric head map is not associated with a synoptic date (or indicates the time period).

- The available potentiometric head map is limited in space.

- Some of the water-level information is not included in the SIPPE2 database.

\section{SIPPE2 Database Limitations}

- There are no humidity measurements.

- There are no wind velocity or direction measurements.

- There are no stage or streamflow discharge measurements.

- There are no stage measurements for lakes, sebkhas, or wadis.

- There are only annual rainfall measurements available in reports.

- There are only annual evaporation and evapotranspiration measurements available in reports.

- There are erroneous measurement values and dates.

- There is no information on hit ratio.

- There is no elevation information associated with drilling sites or well locations.

- There is no water level or flux information collected as part of the Choum-Zouerate numerical modeling study.

- There is no unsaturated zone retention values or saturated hydraulic conductivity values.

- There are an insufficient number of hydraulic head values to construct hydraulic gradients across the country.

- There are an insufficient number of synoptic head values to construct hydraulic regional gradients. 
- There is no information on domestic, industrial, or mining pumping rates.

- There is no information on domestic, industrial, or mining pumping center locations.

- There is no information on recharge rates.

- There is no depth information for water-quality sampling parameters.

- There is no measured dissolved inorganic carbon or dissolved organic carbon.

- There is no measured redox potential (pe) or speciation pairs, iron, manganese, or arsenic.

- There are no measured isotopes or environmental tracers.

- There are no water level measurements associated with the wadis or sebkhas.

- There are no measurements of infiltration or discharge associated with the wadis or sebkhas.

\section{Suggestions}

- Perform quality assurance on all SIPPE 2 data tables.

- Send questionnaires to appropriate agencies, mining and other companies to evaluate availability of additional meteorology (Appendix D), hydrology (Appendix E), and groundwater (Appendix F) data.

- If any of the above data shortcomings can be identified, this information needs to be added to the SIPPE 2 data tables.

\section{References Cited}

Bertone, F., Rendard, P., Kerrou, J., Moix, P., and Perrochet, P., 2006, An assessment of the groundwater resources in the western margin of the Taoudenni basin, Mauritania: in Proceedings International IAH Symposium - Aquifers Systems Management, Dijon, France, Mai, 2006. (PRISM1 HYDRO EVAL 05-2006.ppt)

British Geological Survey, 1996, First Projet de renforcement Institutionnel du Secteur Minier (PRISM-1), 89 p. 
Dassargues, A., 2006, PRISM II — Second project of strengthening of the institutions of the mining sector - An evaluation of the hydrogeologic studies: Sabah Hotel, Nouakchott, Mauritania, $36 \mathrm{p}$.

Friedel, M.J., 2007, Hydrologic model calibration strategy for the Islamic Republic of Mauritania: U.S. Geological Survey Open-File Report in review, 16 p.

Ould Baba Sy, M., and Besbes M., 2006, Holocene recharge and present recharge of the Saharan aquifers; a study by numerical modeling, in Proceedings International IAH Symposium Aquifers Systems Management - Dijon, France, Mai, 2006, 12 p. 


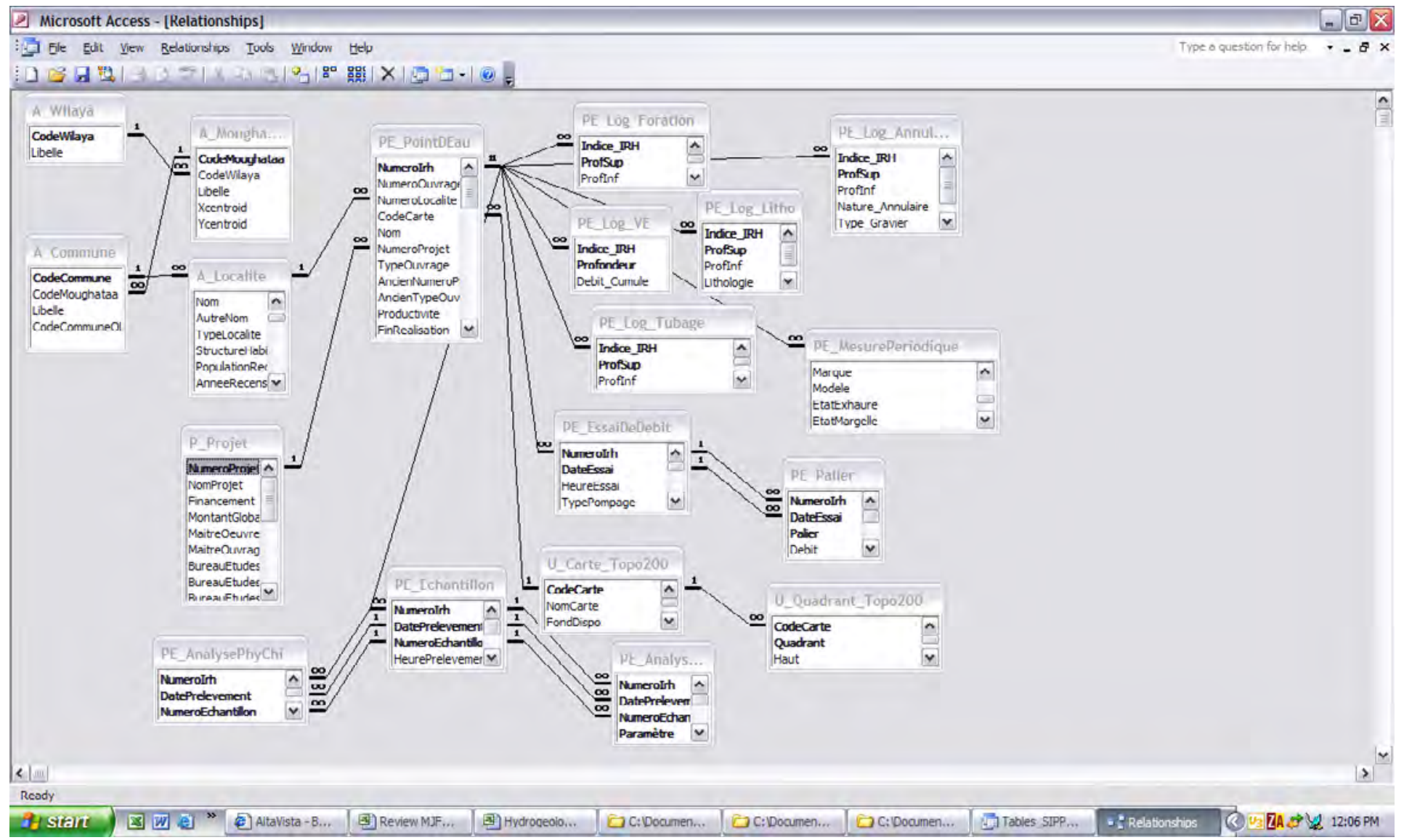

Figure 1. Schematic of relational tables in the SIPPE2 Access database. 


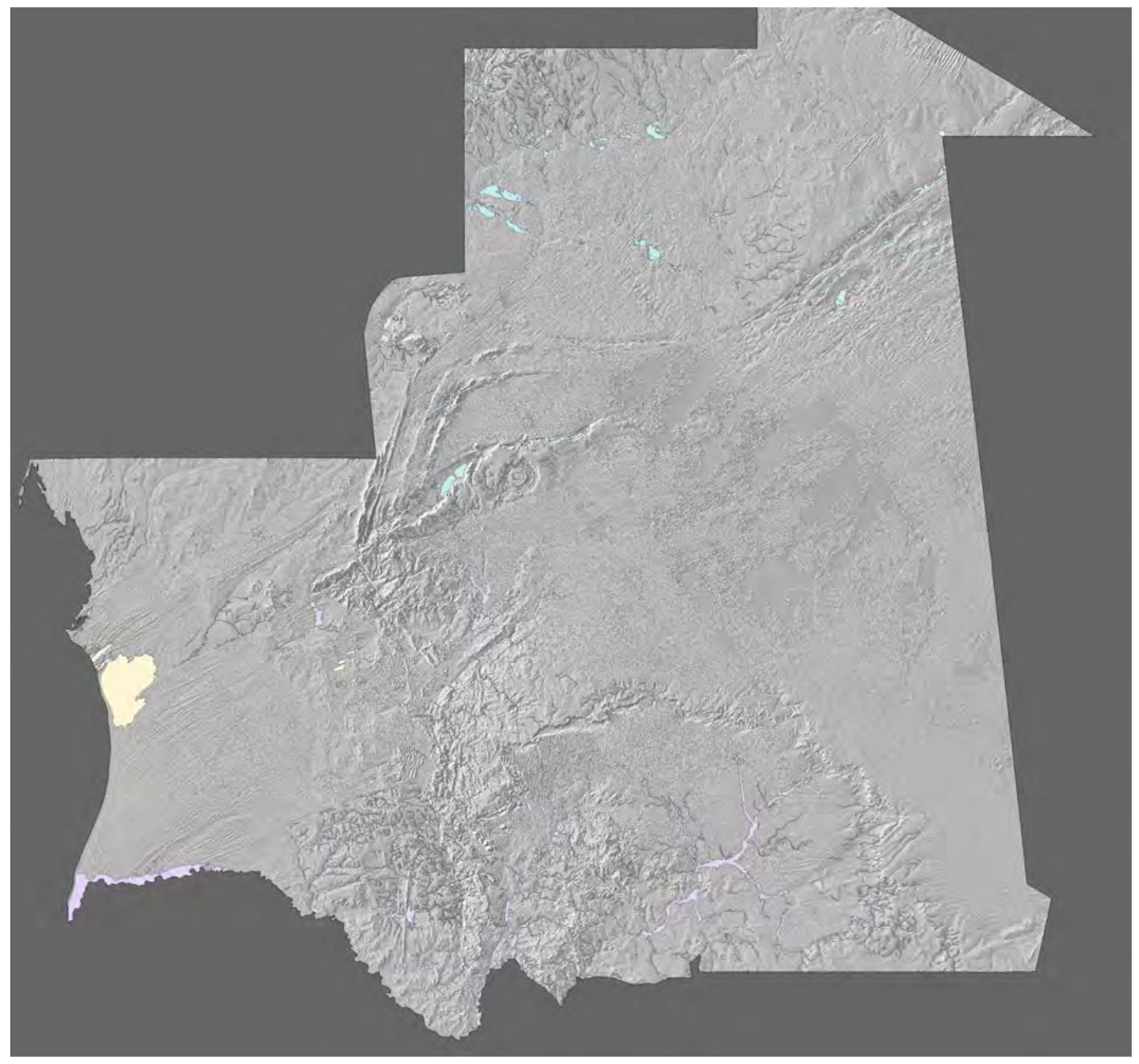

Figure 2. Map of Mauritania, Africa, showing relief (gray), streams (light purple), sebkhas (tan), and lakes (light blue). 


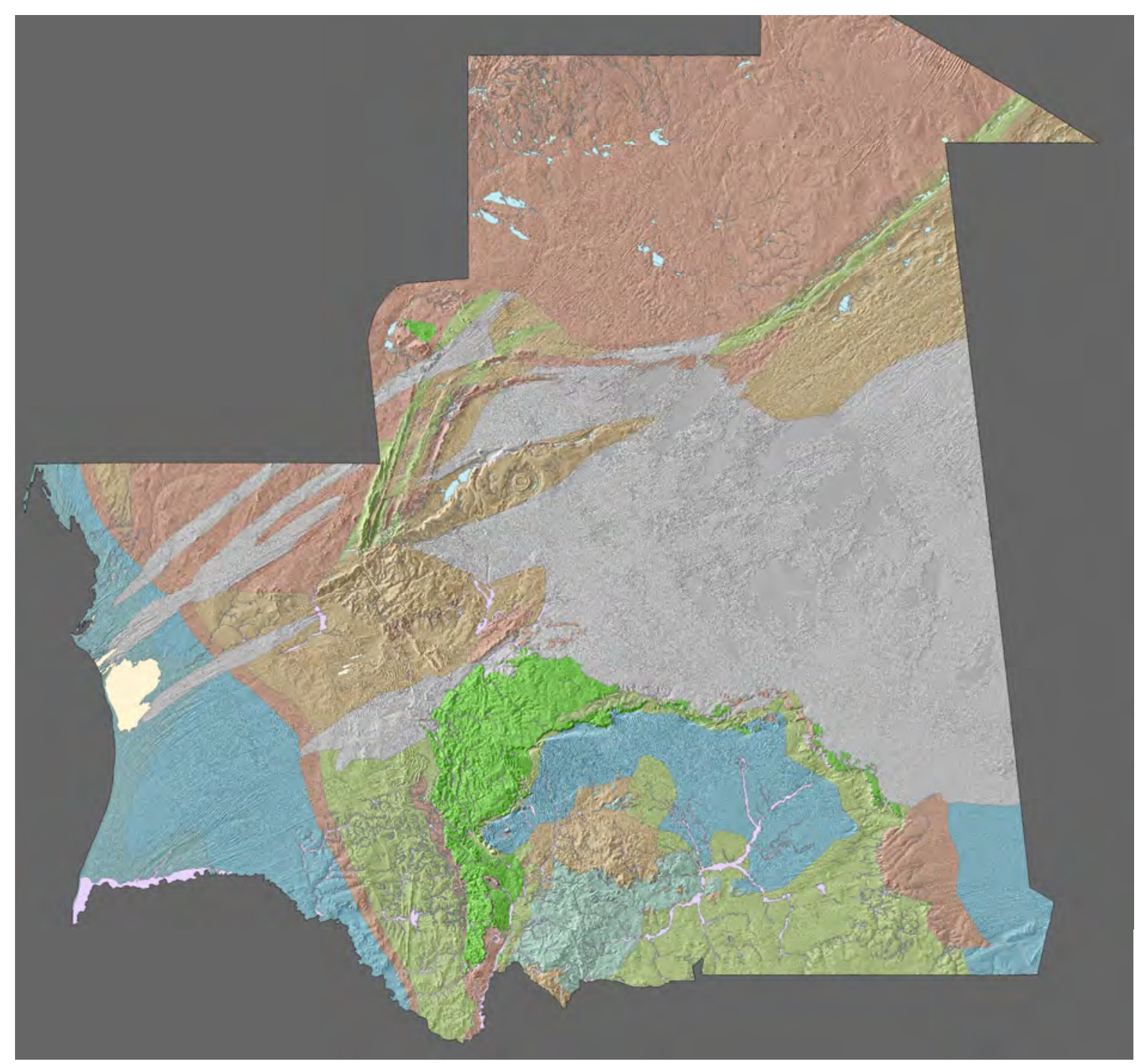

Figure 3. Distribution of aquifers based on success ratio: orange (0-5\%), $\tan (5-45 \%)$, olive green $(45-65 \%)$, light green $(65-85 \%)$, blue green $(80 \%)$, blue $(80-90 \%)$. 


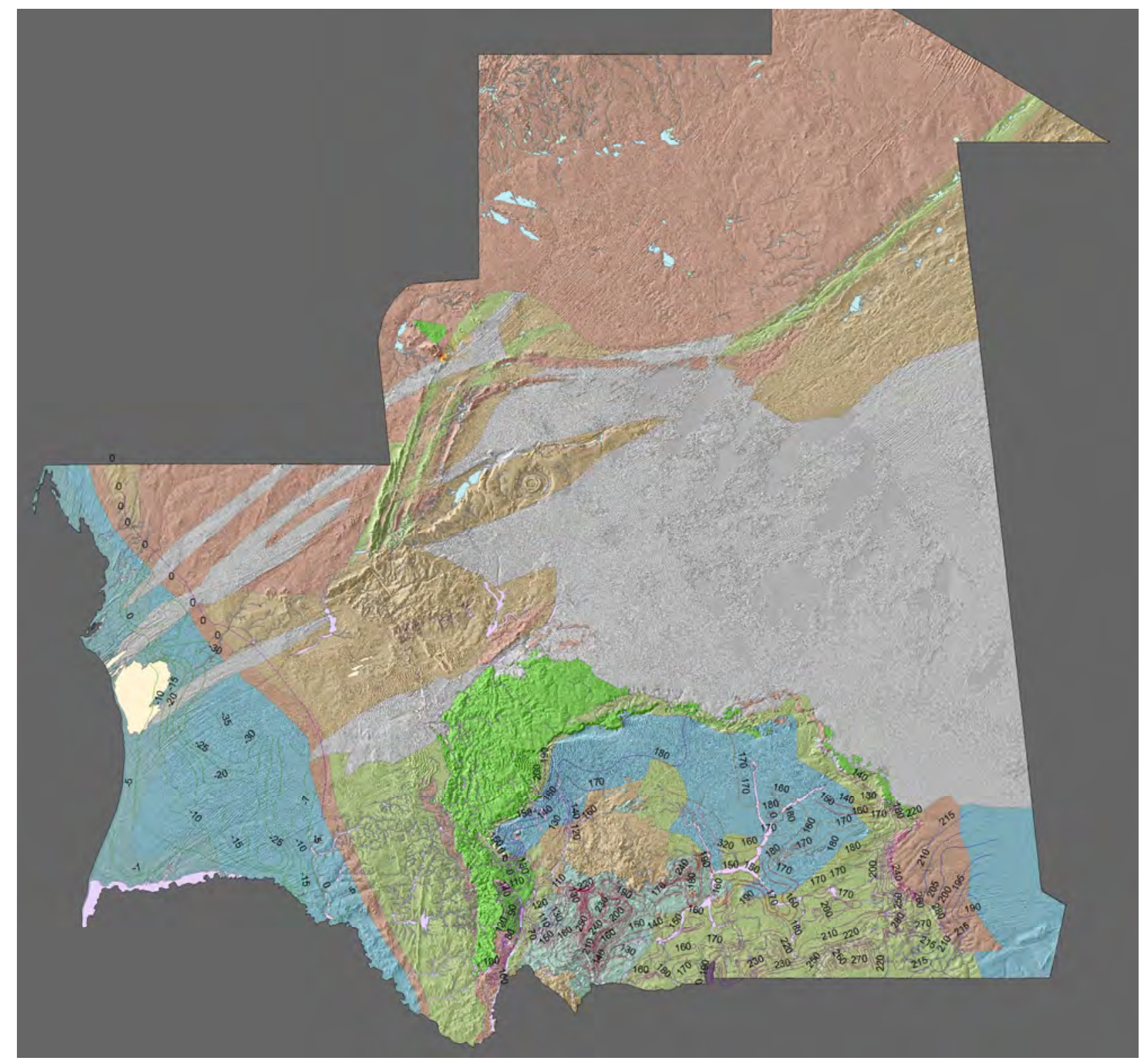

Figure 4. Distribution of hydraulic head values provided as GIS coverages. 


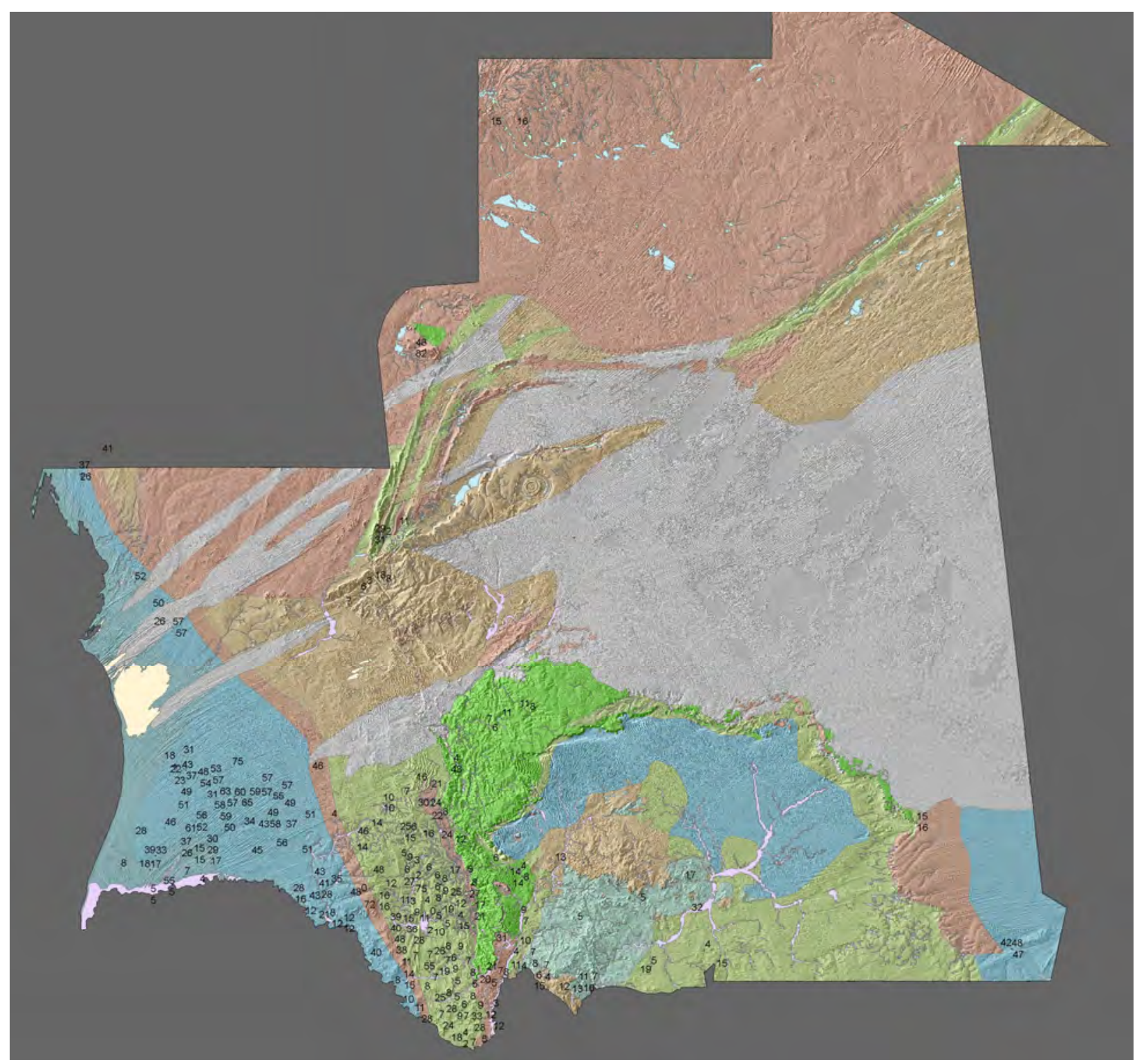

Figure 5. Distribution of measured water levels from the SIPPE2 database. 


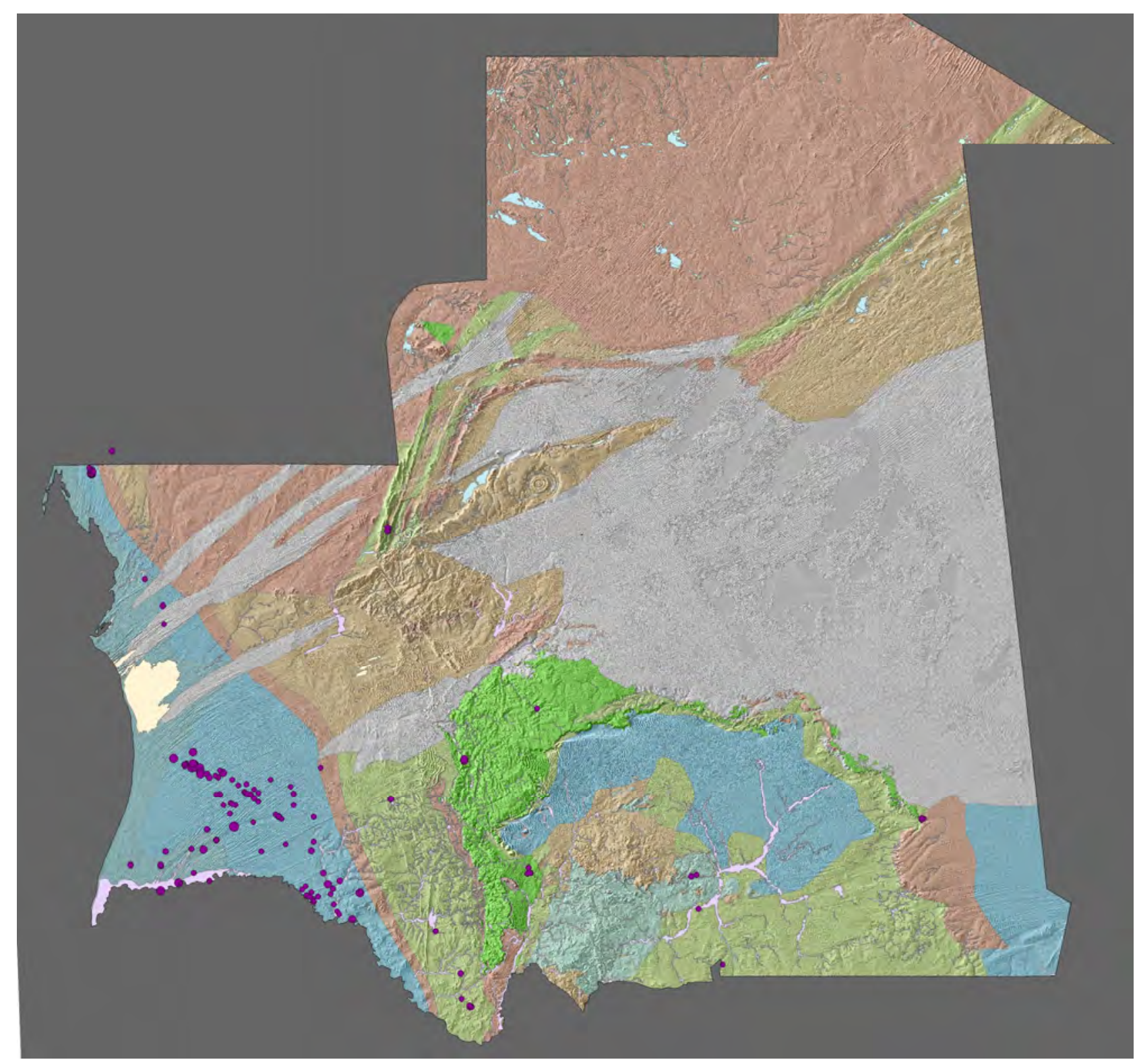

Figure 6. Distribution of aquifer transmissivity values (magenta circles) from the SIPPE2 database. Size of circle indicates relative magnitude of transmissivity. 


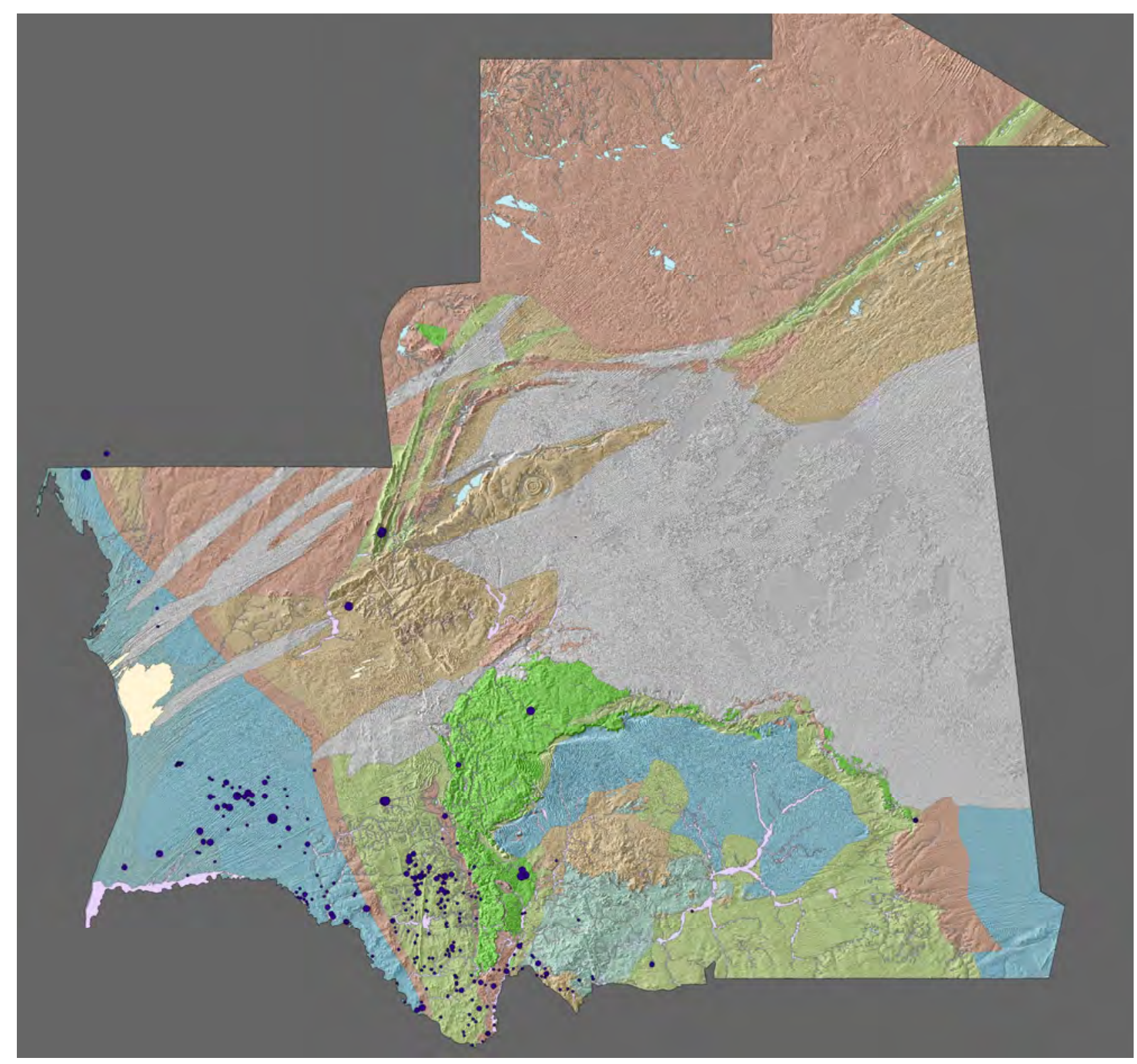

Figure 7. Distribution of dissolved nitrate (purple circles) in ground water from the SIPPE2 database. Size of circle indicates relative magnitude of nitrate concentration. 


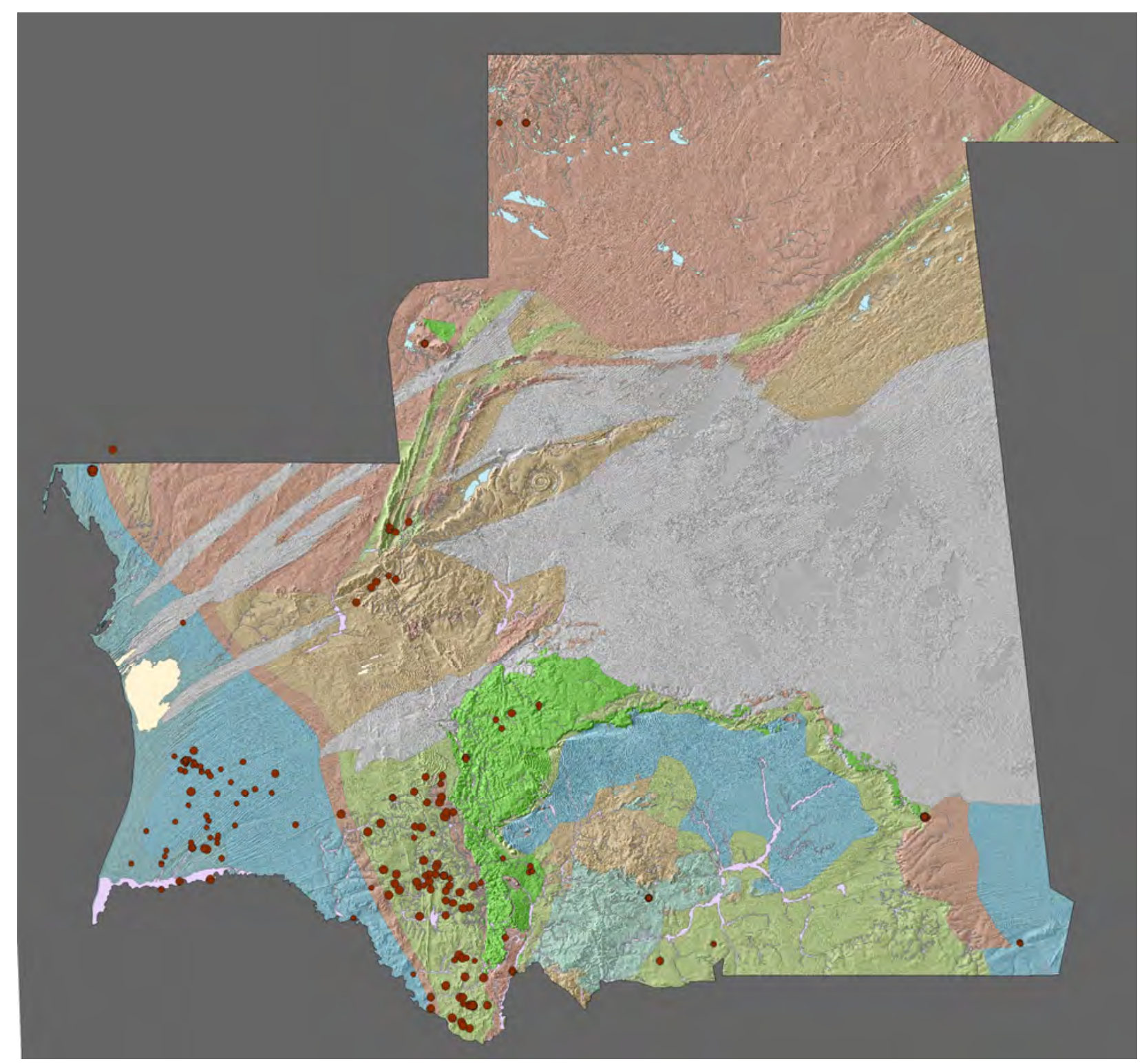

Figure 8. Distribution of dissolved bicarbonate (magenta circles) in ground water from the SIPPE2 database. Size of circle indicates relative magnitude of bicarbonate concentration. 


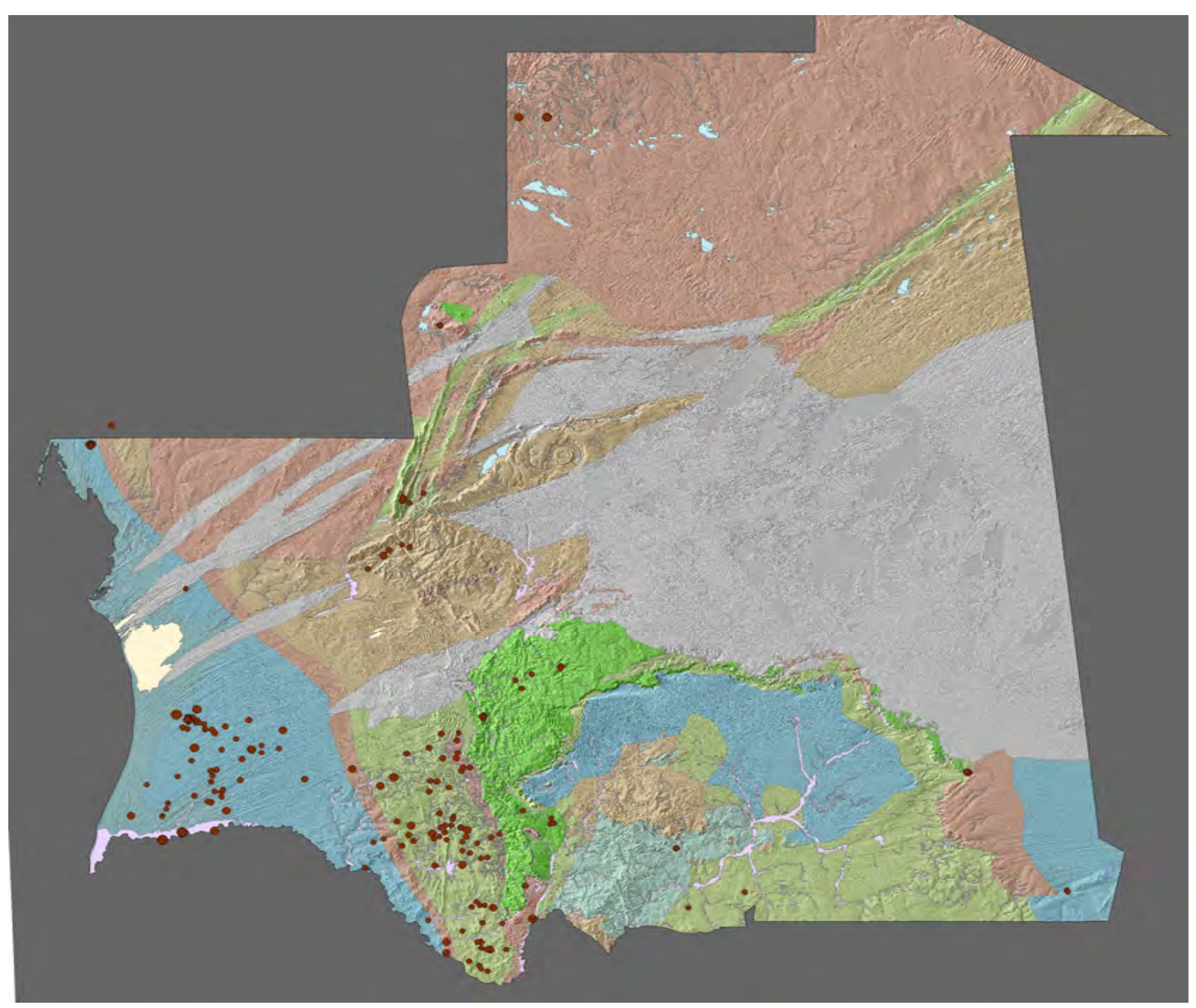

Figure 9. Distribution of dissolved sodium (magenta circles) in ground water from the SIPPE2 database. Size of circle indicates relative magnitude of sodium concentration. 


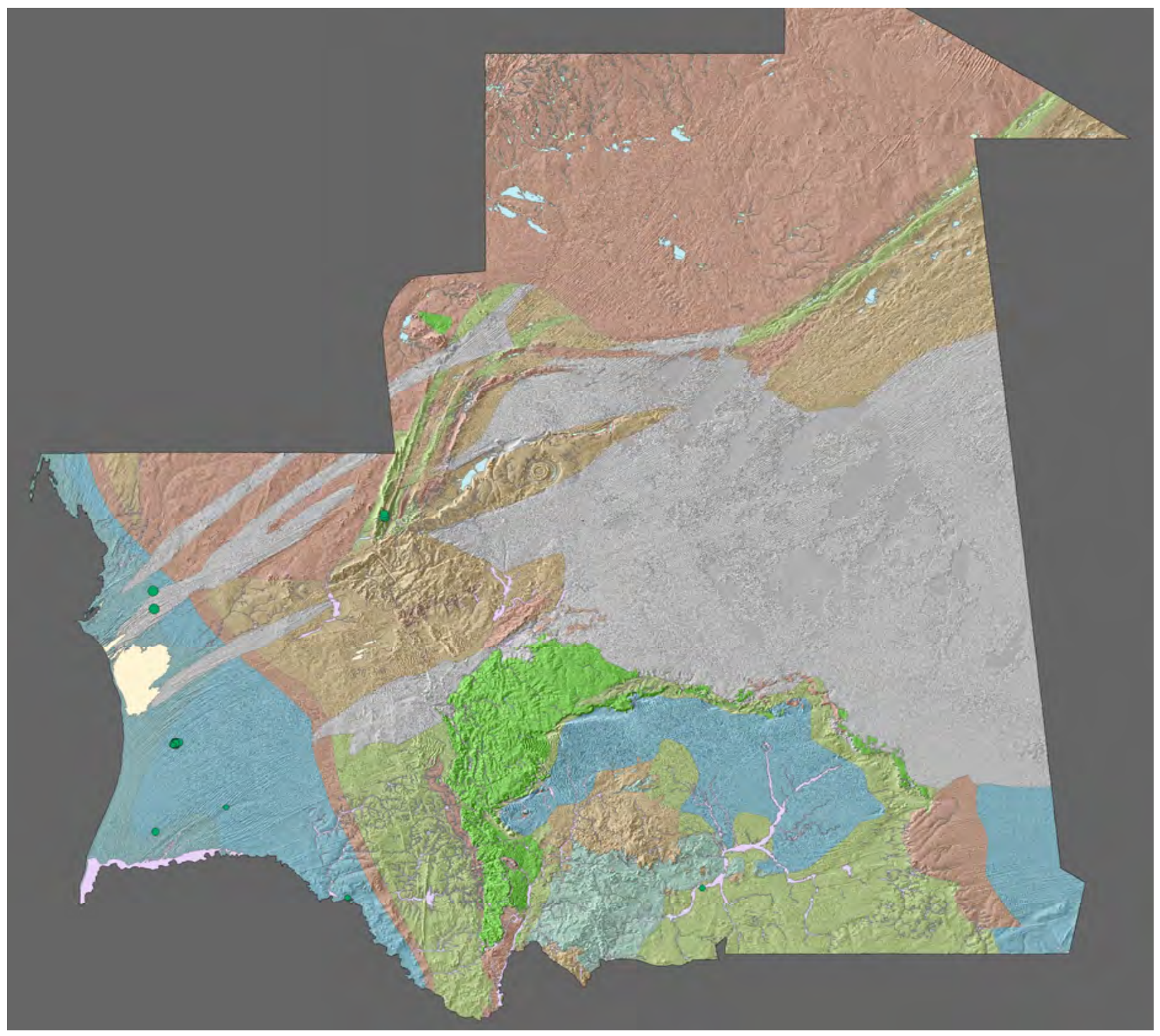

Figure 10. Distribution of dissolved oxygen (green circles) in ground water from the SIPPE2 database. Size of circle indicates relative magnitude of dissolved oxygen concentration. 


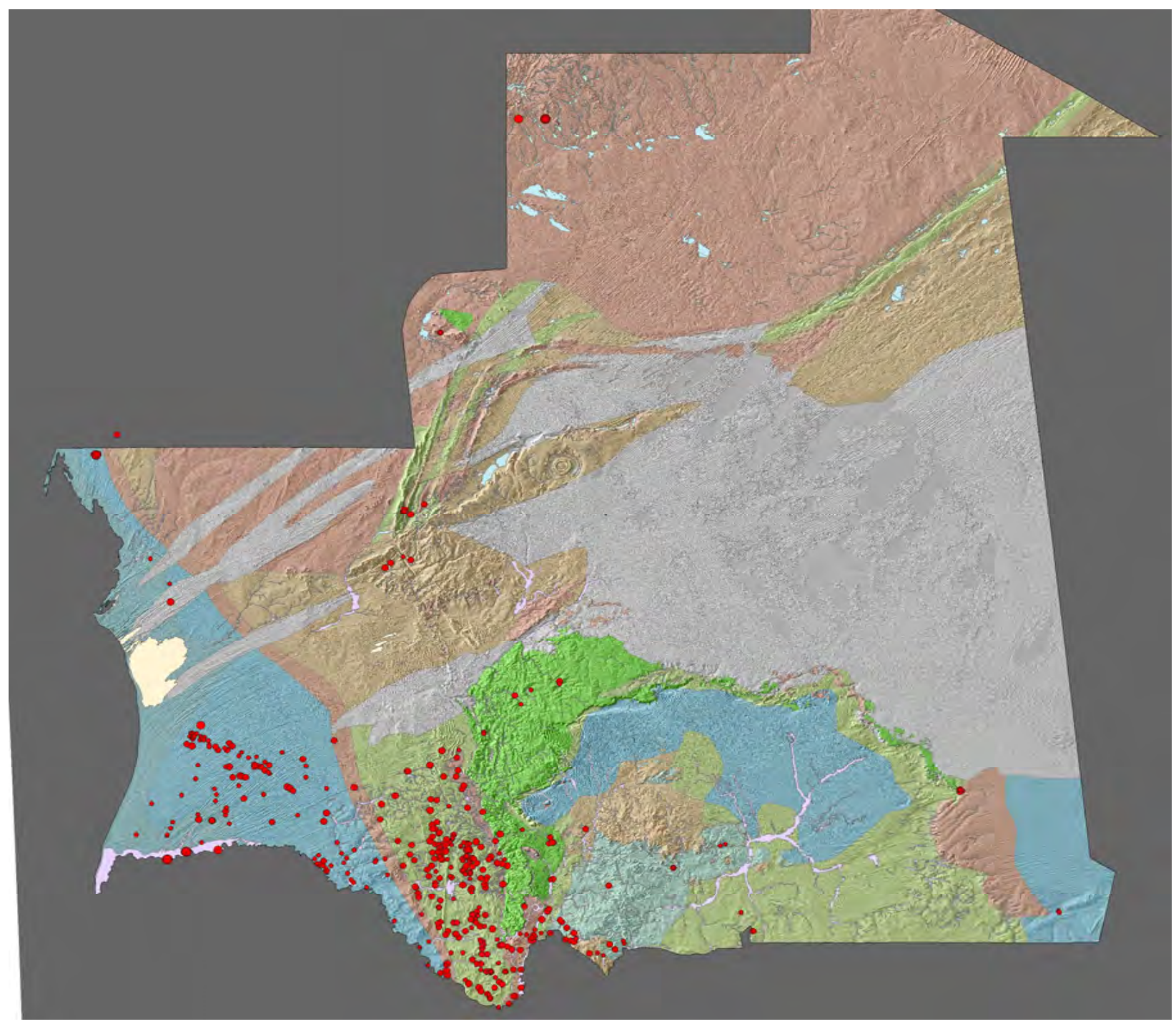

Figure 11. Distribution of electrical conductivity values (red circles) in ground water from the SIPPE2 database. Size of circle indicates relative magnitude of electrical conductivity. 
Table 1. Summary of available annual climate information.

$\left[{ }^{0} \mathrm{C}=\right.$ degree Celsius; $\mathrm{m}=$ meter $]$

\begin{tabular}{lcccccc}
\hline & $\begin{array}{c}\text { Number of } \\
\text { monitoring } \\
\text { stations } \\
\text { no data }\end{array}$ & $\begin{array}{c}\text { Number of } \\
\text { years } \\
\text { monitored } \\
\text { no data }\end{array}$ & $\begin{array}{c}\text { Minimum } \\
\text { No data }\end{array}$ & $\begin{array}{c}\text { Maximum } \\
\text { no data }\end{array}$ & $\begin{array}{c}\text { Average } \\
\text { no data }\end{array}$ & $\begin{array}{c}\text { Northeast direction } \\
\text { Comments }\end{array}$ \\
Wind & no data & no data & 19.2 & 36.9 & no data \\
Temperatures, ${ }^{0} \mathrm{C}$ & 11 & 50 & 3.2 & 5.2 & 4.5 \\
$\begin{array}{l}\text { Evaporation, } \mathrm{m} \\
\text { Potential }\end{array}$ & & & & & Pennman \\
evapotranspiration & & & & & & formula
\end{tabular}

Table 2. Annual evaporation, evapotranspiration, and humidity measurements.

$[\mathrm{mm}=$ millimeters $]$

\begin{tabular}{llllll}
\hline & $\begin{array}{c}\text { No. of } \\
\text { years }\end{array}$ & Minimum & Maximum & Average & Median \\
\hline Evaporation, mm & $\mathbf{2 8}$ & 2081 & 5181 & 3893.67 & 4123 \\
Potential evapotranspiration, $\mathrm{mm}$ & $\mathbf{N o}$ data & 1783 & 2314 & 2156 & 2263.5 \\
$\begin{array}{l}\text { ratio: E/PET } \\
\text { Humidity }\end{array}$ & No data & 1.07 & 2.31 & 1.91 & 2.12 \\
$\begin{array}{l}\text { Precipitation } \\
\text { average (1935-1969), mm }\end{array}$ & & no data & no data & no data & no data \\
average (1970-2004), mm & 34 & 31 & 304 & 152.4 & 138.4 \\
& 34 & 23.6 & 214.7 & 99.8 & 83
\end{tabular}


Table 3. Summary of evaporation at measurement stations across Mauritania.

$[\mathrm{mm}=$ millimeters $]$

\begin{tabular}{|c|c|c|c|c|c|c|c|c|c|c|}
\hline & No. of years & Aioun & Tidjikja & Nema & Boutilimit & Nauadhibou & Nouakchott & Atar & Akjoujt & $\begin{array}{c}\text { Bir } \\
\text { Moghrein }\end{array}$ \\
\hline Evaporation, mm & & 4247 & 4123 & 5181 & 4567 & 2081 & 2421 & 4541 & 3930 & 3952 \\
\hline Potential evapotranspiration, $\mathrm{mm}$ & No data & $\begin{array}{l}\text { no } \\
\text { data } \\
\text { no }\end{array}$ & 1783 & 2314 & 2273 & no data & 2254 & $\begin{array}{l}\text { no } \\
\text { data } \\
\text { no }\end{array}$ & $\begin{array}{l}\text { no } \\
\text { data } \\
\text { no }\end{array}$ & no data \\
\hline Ratio: E/PET & No data & $\begin{array}{l}\text { data } \\
\text { no }\end{array}$ & $\begin{array}{l}2.31 \\
\text { no }\end{array}$ & $\begin{array}{l}2.24 \\
\text { no }\end{array}$ & 2.01 & no data & 1.07 & $\begin{array}{l}\text { data } \\
\text { no }\end{array}$ & $\begin{array}{l}\text { data } \\
\text { no }\end{array}$ & no data \\
\hline Humidity & No data & data & data & data & no data & no data & no data & data & data & no data \\
\hline $\begin{array}{l}\text { Precipitation } \\
\text { average (1935-1969), mm }\end{array}$ & 34 & 304 & 139.8 & 297.5 & 194.1 & 31 & 138.4 & 108.7 & 105.2 & 52.9 \\
\hline Average (1970-2004), mm & 34 & 192.2 & 91.6 & 214.7 & 134.7 & 23.6 & 83 & 70.1 & 57 & 31.3 \\
\hline difference (avg1-avg2), mm & & 111.8 & 48.2 & 82.8 & 59.4 & 7.4 & 55.4 & 38.6 & 48.2 & 21.6 \\
\hline
\end{tabular}


Table 4. Summary of groundwater physical parameter and chemical concentrations from SIPPE2 database.

$[\mathrm{O} 2=$ dissolved oxygen, $\mathrm{Temp}=$ temperature, Cond $=$ electrical conductivity, $\mathrm{S} 04=$ sulfate, $\mathrm{NO} 3=$ nitrate, $\mathrm{Na}=$ sodium, $\mathrm{Mg}=$ magnesium, $\mathrm{HCO} 3=$

bicarbonate, $\mathrm{IQR}=$ interquartile range $;{ }^{0} \mathrm{C}=$ degree celsius; $\mu \mathrm{S} / \mathrm{cm}=$ microSiemens per $\mathrm{cm} ; \mathrm{mg} / \mathrm{l}=$ milligrams per liter; $\mathrm{m}=$ meters; $\mathrm{m} / \mathrm{s} \mathrm{meters} \mathrm{per} \mathrm{second;} \mathrm{m}^{2} / \mathrm{s}$ $\underline{=\text { square meters per second] }}$

\begin{tabular}{|c|c|c|c|c|c|c|c|c|c|c|c|c|c|c|}
\hline Statistic & $\underset{\mathrm{mg} / \mathrm{l}}{\mathrm{O}_{2}}$ & $\begin{array}{c}\text { Salinity } \\
\mathrm{mg} / \mathrm{l}\end{array}$ & $\begin{array}{l}\text { Ph } \\
--\end{array}$ & $\underset{{ }^{0} \mathrm{C}}{\text { Temp }}$ & $\begin{array}{l}\text { Cond } \\
\mu S / \mathbf{c m}\end{array}$ & $\begin{array}{l}\mathrm{SO}_{4} \\
\mathrm{mg} / \mathrm{l}\end{array}$ & $\begin{array}{l}\mathrm{NO}_{3} \\
\mathrm{mg} / \mathrm{l}\end{array}$ & $\underset{\mathrm{mg} / \mathrm{I}}{\mathrm{Na}}$ & $\underset{\mathrm{mg} / \mathrm{I}}{\mathrm{Mg}}$ & $\begin{array}{l}\mathrm{HCO}_{3} \\
\mathrm{mg} / \mathrm{l}\end{array}$ & $\underset{\mathrm{mg} / \mathrm{I}}{\mathrm{Ca}}$ & $\begin{array}{c}\text { Permeability } \\
\mathrm{m} / \mathrm{s}\end{array}$ & $\begin{array}{c}\text { Transmissivity } \\
\mathrm{m}^{2} / \mathrm{s}\end{array}$ & $\begin{array}{c}\text { Water } \\
\text { Level, } \\
\text { m }\end{array}$ \\
\hline Count & 27 & 221 & 569 & 380 & 571 & 287 & 391 & 281 & 293 & 281 & 296 & 77 & 150 & 470 \\
\hline Minimum & 0.00 & 0.0 & 6.00 & 23.0 & 1.0 & 0.0 & 0.0 & 0.0 & 0.0 & 2.0 & 1.0 & 0.0000003 & 0.0000038 & 0.0 \\
\hline Maximum & 17.59 & 16489.0 & 9.00 & 37.6 & 19040.0 & 1900.0 & 115.0 & 3524.0 & 588.0 & 5499.0 & 1214.0 & 0.005796 & 0.0694 & 82.2 \\
\hline Average & 4.24 & 848.6 & 7.44 & 32.5 & 985.4 & 96.9 & 4.9 & 150.4 & 28.5 & 242.2 & 72.3 & 0.000332643 & 0.007285812 & 23.3 \\
\hline $\begin{array}{l}\text { Standard } \\
\text { deviation } \\
\text { 25th }\end{array}$ & 3.57 & 1896.5 & 0.54 & 2.5 & 1364.7 & 195.3 & 11.9 & 376.5 & 50.1 & 348.3 & 113.5 & 0.000972798 & 0.012609859 & 17.3 \\
\hline $\begin{array}{l}\text { percentile } \\
50 \text { th }\end{array}$ & 3.04 & 252.0 & 7.00 & 31.8 & 457.0 & 12.5 & 0.2 & 30.0 & 8.0 & 94.0 & 25.8 & 0.00000856 & 0.000281389 & 9.7 \\
\hline $\begin{array}{l}\text { percentile } \\
\text { 75th }\end{array}$ & 4.00 & 374.5 & 7.47 & 33.0 & 731.0 & 35.0 & 1.2 & 55.0 & 14.0 & 192.1 & 47.5 & 0.00005 & 0.0021 & 17.8 \\
\hline $\begin{array}{l}\text { percentile } \\
\text { Inter } \\
\text { quartile } \\
\text { range }\end{array}$ & 5.00 & 700.0 & 8.00 & 34.0 & 1028.5 & 92.0 & 4.6 & 103.0 & 30.0 & 298.3 & 74.0 & 0.0001965 & 0.0081375 & 34.3 \\
\hline $\begin{array}{l}(\mathrm{IQR}) \\
1.5 * \mathrm{IQR}\end{array}$ & 1.97 & 448.0 & 1.00 & 2.2 & 571.5 & 79.5 & 4.4 & 73.0 & 16.0 & 204.3 & 48.3 & 0.00018794 & 0.007856111 & 24.6 \\
\hline$=$ & 2.95 & 672.0 & 1.50 & 3.3 & 857.3 & 119.3 & 6.6 & 109.5 & 24.0 & 306.4 & 72.4 & 0.00028191 & 0.011784167 & 36.9 \\
\hline
\end{tabular}




\section{Appendix A}

Overview of Hydrogeologic Information Provided to the USGS 
Table 5. Hydrogeologic information found in the Carte Hydro choumZte folder.

Folder

Subfolder

\section{ICarte Hydro choumZte}

1

Zipped and picture files: rar, tiff

Atar50k.rar, Char50k.rar, Chinguetti50k.rar, F'Derik50k.rar, OumDFeirat50k.rar, Tourine50k.rar

Document files: pdf

Overview of hydrogeology in the Zouerate; Hydrogeol_Notice_explicative.pdf

Report on numerical modeling around Zouerate to understand influence of mining;

Modelisation_2D_(version_provisoire).pdf

Report on drilling; Implantation_forages(version_corrigee).pdf

Report on regional management; Plan_de_gestion(version_provisorie).pdf

Rapport_Terrain.pdf

Report on satellite imaging; teledection_(version_provisoire).pdf

Table 6. Hydrogeologic information found in subfolders of the Rapports folder.

\section{Folder \\ Subfolder \\ Vapports \\ Formation}

Document files: doc

Training course - data bases; hydrogeologic synthesis; formation.pdf; Formation_BDD.doc

Glossary; glossaire_extrait.doc

Subfolder

\section{INotice Hydrogeol}

Excel and document files: $x l s$, doc

Formation, groups, geology at 1/200k, 1/500k, 1/1000k for areas: HANK ZERMA, ADRAR. TAGANT, ASSABA /

AFFOLE / HODH; Annexe 1- Annexe 1 Echelle stratigraphique.xls

Pages includes drilling in groups/areas, success $>1 \mathrm{~m} 3 / \mathrm{hr}$ (pumping?), pages by lithology: Grès Dar Taleb El Aguer, Grès, Dolomie calcaires, granite, Mauritanides (lithology sections by wilaya - management region - no drillhole locations);

Annexe 2 - Notice Analyse resultats forages.xls

Pages by area (Tijirit Amsaga, Reguibat LB, Imourène Sougy Delpy LB, Bir Moghrein TECSULT) with various studies (wells information (deg, min, sec; quality of water, formation lithology, ...) for areas Tijirit Amsaga and Bir Moghrein TECSULT (concentrations, g/l) and Bir Moghrein TECSULT ((3 dates water level - declining); Annexe 3 - Puits IMOURENE REGUIBAT TIJIRIT BIR MOGRHEIM.xls

Pages by area (A4 Aouker Baretto), ...one study PUITS AOUKER (INVENTAIRE BARRETO 1961) with information: $\mathrm{x}, \mathrm{y}, \mathrm{z}$ (ground elev), concentration g/l, some prod. Rates, 3 water levels w dates (NS/sol m?), most water levels for 1961- 
Subfolder

Subfolder

Subfolder

Subfolder

Subfolder
62, formation lithology; Annexe 4 - Puits AOUKER.xls

Pages by area (TIJIRIT, ZEMMOUR NOIR, AMSAGA, TIRIS); each page various projects (coordinates, depth, some water levels, some concentrations, lithology described over intervals); Annexe 5 - solndages MAU67-502 TIJIRIT

ZEMMOUR NOIR AMSAGAT.xls

Overview by region: economic activities (agriculture, mining, ...), climate (average annual precipitation, temperature, evaporation, evapotranspiration), summary of geology (..);Noticartehdro_SR_last.doc

\section{IR1- Demarrage}

Excel and document files: xls, doc

Discussion aquifers (continuous, discontinuous, others, geophysics); SIPPE, HYGES data bases and proposed structure new SIPPE2 (PRISM II) ; training; computer equipment; overview drill log software (6); Rapport R1-Evaluation-

\section{R4827a.doc}

\section{IR2 Notice SIPPE2}

Document files: doc

SIPPE2 (PRISM II) data base: installation, overview, and use of the management interface (gui pics); Rapport R2 Notice SIPPE2_complet.doc

\section{$\backslash \mathbf{R 3}$ - Activite saise et digit}

Excel and document files: xls, doc

Annexe 1 liste projects saise coupes forgaes.xls

Annexe 2 PE avec nIRH modifie.xls

Annexe 4 Erreurs coordonnees.xls

Biblio_HC.xls

glossary of agencies; overview of drilling information including piezometers (number location; references), geological and salinity information; appendix 1 primary aquifers (1/500k), Appendix 2: reports and docs used for water points; Appendix 3: drilling amended; Appendix 4: coordinate errors for water points; Appendix 5: geological formations (hydrostratigraphic legend); R 4890 - Rapport R3 final BGP.doc

\section{R4 Rapport final}

Document files: doc

Overview SIPPE2 (PRISM II) database, technical information (drilings, piez, etc.), gant chart, ...; Rapport R4-Rapport final.doc

\section{$\backslash$ R4 Rapport final}

Document files: doc, pdf

Project overview; data processing examples including annual pump volume (1969-2004); changing salinity in piez (different regions) 1965-2005; average (35 years - 1970-2004) precipitation (mm) by stations (25); figures primary aquifers; Rapport T1-Activitie.doc; Rapport T1-Activitie.pdf 
Table 7. Hydrogeologic information (PRISM-2) found in subfolders of the SIPPE2 folder.

Folder (PRISM II)

Subfolder

Subfolder

Subfolder

Subfolder

Subfolder

Subfolder

\section{ISIPPE2}

Application and other files: exe, mwd,

program used as part of management data base SIPPE2.mbd (not used in inventory); ACCES_SIPPE2.mwd program used to compact files when management data base SIPPE2 (PRISM II) set up properly (not used in inventory);

compactcurrent.exe

shortcut for desktop; requires setting locations for databases etc.; requires username and password (not used in inventory); Lancement de SIPPE2

This database has management interface linked to Tables_SIPPE2.mdb; doesn't work unless shortcut is set up properly; SIPPE2.mdb primary data base used to retrieve and evaluate data sets (requires setting up and running queries); 30 tables with multiple primary keys: each described separately below; Tables_SIPPE2.mdb

\Add_On

Application and other files: exe, zip

Mapinfo6.5.exe

WinZip.exe

MenuTools.zip

MenuTools_Old.zip

MW_Fonts.zip

AARCHIVE

Text files: txt

Liste_Zip.txt

Liste_xZip.txt

Docs

Excel and document files: xls, doc

Dictionary; Dictionnaire BDD.xls

Overview of SIPPE2 database management applications ; Noitce SIPPE2_complet.doc

Bibliography; Biblio_HC.xls

Image

Excel and picture files: xls, gif, jpg

Various images; *.xls

Various logos; *.gif

Relational structure of database; Structure.jpg

iDem 
Digital elevation model files: img, rrd

Aster dem files: rrd, aux

Aster info files: dat, nit, 001

Aster mnt_projecte files: adf, xlm

Table 8. Hydrogeologic information found in subfolders of the Hydrology folder.

Folder

Subfolder

Subfolder

Subfolder

Type:

Files:

Subfolders

Type:

Files:

Subfolders

Type:

Files:
C:IMauritanialMauitania_workl|Hydrology

\section{Idecors divers}

GIS files: dbf, sbn, sbx, xhp, prj

Arf_pays, cadre_nom_point, cadre_rectangle, commune, cote, hydro_lingne, hydro_pol, hydro_pt, mines, newhspe, orog_ligne, orog_pt, pays, physiographie_ligne, pt-eau, pt-rouge, rail, regions,

routes, $t \_$aviation, villes

Ifiguré

Picture files: bmp

Typical fills for geologic features

Hydrogeol

GIS files: dbf, sbn, sbx, xhp, prj

aquifere, barrage, Centre_Qoueds, Centre_Sebkha_region, eau_ressource_region,

Fractures_digit_yom_polyline, Fractures_digit_yom_region, Nord_Hydrogeol_Yom_polyline,

Nord_Hydrogeol_yom_region, Nord_Oueds_yom_region, Nord_Sebkha_rectangle,

Nord_Sebkha_region, Sud_Oueds_region

Ipiézométrie - salinitélAutresPiezos

GIS files: dbf, sbn, sbx, xhp, prj

Aouker piezo Est_polyline, Aoukerest salinite_region, Aoukerpiezo Ouest_polyline, Assabapiezo_polyline,

Biceausecdhar2_polyline, Dhanemapiezo_polyline, LimiteappeAoukar_point, LimitenappeAoukar_polyline,

LimitenappaoukerOuest_polyline, Piezoaoukar_polyline, PiezohodhgrresAioun_polyline, PiezopelitHodh_polyline,

Pluviometriea_polyline, Pluviometrieb_polyline, Rosso_biseau_sale_polyline

Ipiézométrie - salinitélPIEZO CHINOIS

GIS files: dbf, sbn, sbx, xhp, prj

PiezoChinois_polyline 
Subfolders

Type:

Files:

Subfolders

Type:

Files:

Subfolders

Type:

Files:

Subfolders

Type:

Files:

Subfolder

Type:

Files:

Subfolder

Type:

Files:
Ipiézométrie - salinité Piezo Nord Traza

GIS files: dbf, sbn, sbx, xhp, prj

Limitenappe_point, Limitenappe_polyline, Limitenappe_region, Limitenappe_text, PiezonordTraza_polyline, SaliniteTrarza_point, SaliniteTrarza_polyline

Ipiézométrie - salinitélSALINITE CHINOIS

GIS files: dbf, sbn, sbx, xhp, prj

Salinitechinois_polyline

Ipiézométrie - salinitélTRARAZA PIEZO

GIS files: dbf, sbn, sbx, xhp, prj

LimitenappePaloc_point, LimienappePaloc_polyline, LimitenappePaloc_region, LimitesocletrarzaCP_point,

LimitesocletrarzaCP_polyline, Piezo Trarza_point, Piezo Trarza_polyline, Piezo Trarza_text

|piézométrie - salinitélTRARAZA SALINITE

GIS files: dbf, sbn, sbx, xhp, prj

Trarzasalinite_polyline

Ipt_eau

GIS files: dbf, sbn, sbx, xhp, prj

Barrage_point, barrages_font_point, PE_point, sondages_point, source_font_point,

SR-ListeDesPE-new_font_point, stations_hydrologiques_point

ISIG_Geol_500

GIS files: dbf, sbn, sbx, xhp, prj

Nord_Geol_Con_Phase1, Nord_Geol_Div_phase1, Nord_Geol_Pol_Phase1, Nord_Geol_Pol_Phase1,

Nord_Geol_Pol_Phase1a, Nord_Geol_Str_Phase1, Sud_Geol_Div_Phase1, Sud_Geol_Pol_Phase1 
Table 9. Hydrogeologic information found in subfolders of the SIGE folder.

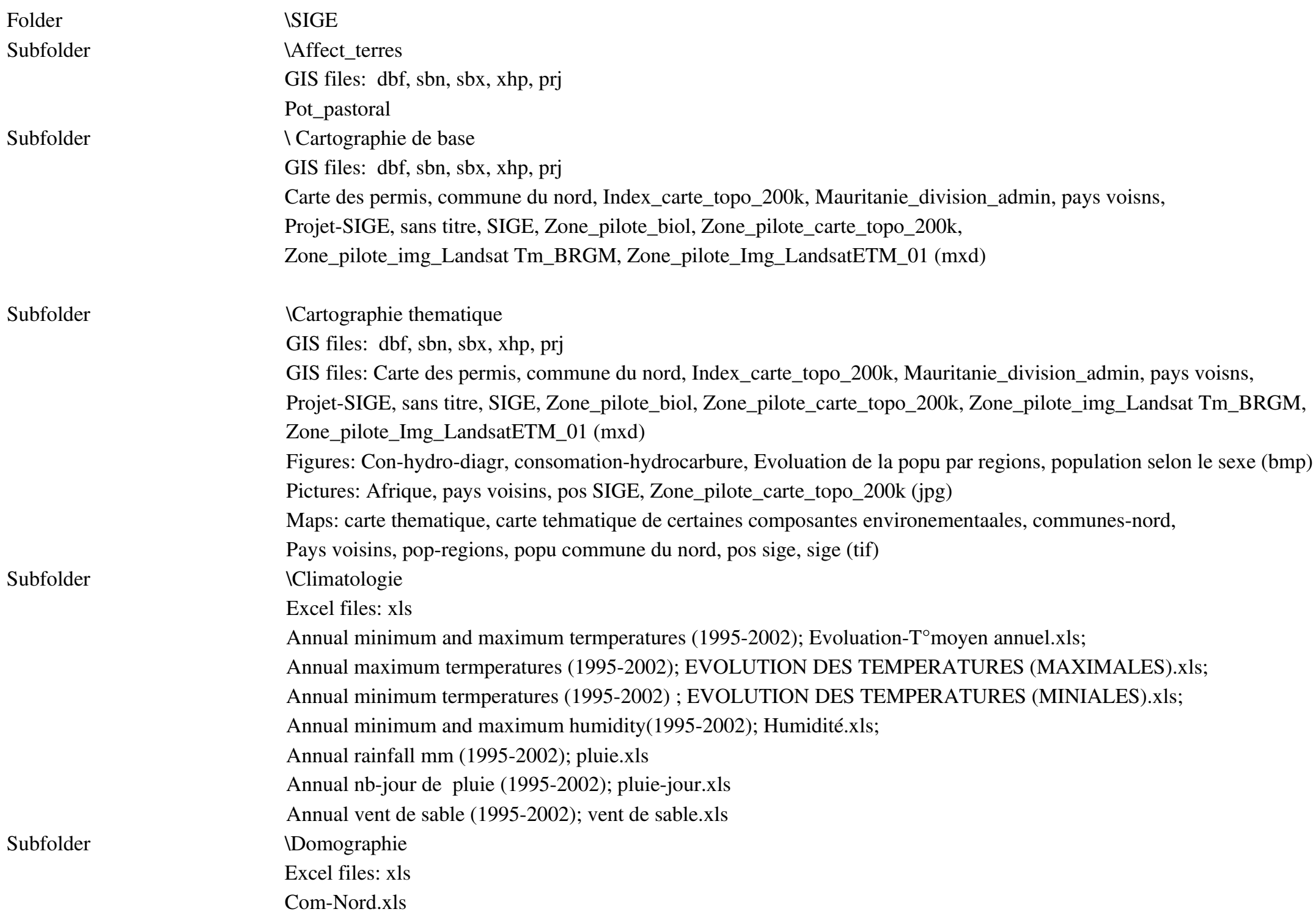


pop NDB.xls

pop-région.xls

Population de la Wilaya de Dakhlet Nouadhibou.xls

repar par age.xls

Rép-pop-sex.xls

Taux net de migration.xls

Subfolder

Hydrographie

GIS files: dbf, sbn, sbx, xhp, prj

Cours_eau, Plan_eau_a, Plan_eau_b (dbf, prj, sbn, shp, shx)

Subfolder

Hydrographie

GIS files: dbf, sbn, sbx, xhp, prj

Cours_eau, Plan_eau_a, Plan_eau_b

Subfolder

$\checkmark$ Hydrologie

GIS files: dbf, sbn, sbx, xhp, prj

hydro_ligne, hydro_pol

Subfolder

$\backslash$ Point d'eau

GIS files: dbf, sbn, sbx, xhp, prj

hydro_ligne, hydro_pol, hydro_pt

Subfolder

$\backslash$ Textes reglementaires $\backslash$ Legislation minere-Anglais

Text files: doc, pdf

Legal documentation

Subfolder

ITransport

GIS files: dbf, sbn, sbx, xhp, prj

rail, route, route_pist, t_aviation, urban_ar, Voie_ferree

Subfolder

IVilles_localites

GIS files: dbf, sbn, sbx, xhp, prj

cites, villes, villes_principal, schema

Other files: DAT, ID, IND, MAP, TAB

Belediyat 


\section{Appendix B}

Overview of Tables in the PRISM-2 (SIPPE2) Relational Database 
Table 10. Overview of tables and fields found in the SIPPE2 database.

[NAME_NAME = database table name; italicized codes are fields in the tables]

Table

A_Commune

A_Loc_Population

A_Localite

A_Localité absentes dans la table

A_Localite

A_Moughataa

A_Wilaya

Lexique_A

Lexique_PE

Lexique_Projet

PE_AnalyseBact

734

PE_AnalysePhyChi
Number Records
Comments/Fields

Code relationships

CodeCommune, CodeMoughataa, Libelle, CodeCommuneOLD

Community information

NumeroLocalite, AnneeRecensement, PopulationRecensee, Source, Code, Recensem, Observation Population, number of wells, latitude, longitude (hr,min,sec); Xcoor, Ycoor (dec degrees)

Codes, population, census date

Code, NumeroLocalite, AnneeRecenser, PopulationRecente, DateRecensemente

City names and centroid of Wilya (regional administration)

Libelle, Xcentroid,Ycentroid

Codes and names of regional management units

CodeWilaya, Libelle

Lexicon

Lexicon, codes, descriptions

Champ, Code, Libelle

Champ (Active, Aptitude, Aquifere, Couleur, Diagnostic,Etat, Fluide, Laboratoire, Lighologie [001-165], Marque, Methode, MethodeForation, MethodInterpretation, Modele,

Nature_Annulaire, Nature_Tubage, NatureAquifere, NatureCaptage, NomNappe, Odeur,

OrigineCoord, Parametre_Bact, Parametre_PC, Prodcutivite, RepereMesure, Salubrite, Saveur, Stratigraphie, Turbidite, Type_Gravier, Type_Tubage, TypeAquifere, TypeExhaure, TypeOuvrage, TypePompage, Usage, Utilisation), Code, Libelle (descriptions)

Agency, code, project name

Sample dates, parameters (coliform, e-coli, germs, streptocaucus) - 1967-2003

Numerolrh, DatePrelevement, NumeroEchantil, Parametre, DateAnalyse, HeureAnalyse, Unite, Valeur_num, Valeur_txt

Parametres (aluminum, ammonium, bicarbonates, calcium, fer, fluor, manganese, magnesium, nitrates, nitrites, phosphates, silice, sodium, sulfates; chlorures, aptitude, oxygeneDiss, $\mathrm{Ph}$, conductivite, couleur, temperature); units: ${ }^{\circ} \mathrm{C}$, uS.m, $\mathrm{mg} / \mathrm{l}$ 
PE_Echantillon

PE_EssaiDeDebit

PE_Log_Annulaire

PE_Log_Foration

PE_Log_Litho

PE_Log_Tubage

PE_Log_VE

PE_MesurePeriodique
Numerolrh, DatePrelevement, NumerocEchantillon, Parametre, DateAnalyse, HeureAnalyse, Unite, Valeur_num, Valeur_txt, Observation

QA problems with dates? For example, 1900-2008

3816 records 1900-1901?

2387 records 1900 ?

$1955,1959,1964,67,68,72,7374,75,76,80,85,86,87,89,90$,

Date, ... laboratory, observations (cells mostly empty)

Numerolrh, DatePrelevement, NumeroEchantil, HeurePrelevement, Preleveur, Laboratoire, Observations Pump test information includes type of test, transmissivity, permeability (not fully populated)

Numerolrh, DateEssai, HeureEssai, TypePompage, CoteRepreeMesure, NiveauStatiqueAvantEssai, MethodInterpretation, DebitCritique, RabattlementCritique, DebitSpecifique, Transmissivite, Permeabilite, Emmagasinement, EssaiSaisi

QA problems - some $\mathrm{K}>\mathrm{T}$ (many duplicate records (actually 77)

Information for well completion

Indie_IRH, ProfSup, Profinf, Nature_Annulair, Type_Gravier, Diametre

Upper and lower screen/casing?, diameter of casing, drilling method, fluid

Indice_IRH, ProfSup, Profinf, Diametre, Methode, Fluide

Lithology between screened interval

Indice_IRH, ProfSup, Lithologie, Description

Drilling and casing information

Indice_IRH, ProfSup, ProfInf, Type_Tubage, Nature_Tubage, Diametre

Note: 1356 holes with no apparent casing (mixing)

No comment

Depth work, depth water, level piezometrique, color, odor, turbidite, flavor, mark, models, state pumping, state margelle, state sidewalk, state cloture, state ant quagmire, abreuvior, irrigation, maitrise waters, sale water, reseau,

NumeroIrh, DateVisiteTerrain, CoteRepereMesure, ProfondeurOuvrage, ProfondeurEau, Productivite, Activite, NieveauPiezometrique, Temperature, Conductivite, Ph, Couleur, Odeur, Turbidite, Saveur, Utilisation, DebitExploite, TypeExhaure, ...

$\mathrm{Ph}$ range; 0.8 - 737.3 - QA problems

Conductivite range:6 - 67000 - QA problems

Temperature range: 3.5 - 32532.5 - QA problems

NieveauPiezometrique: range: 2.5 - 121 - QA problems? 
SNIM_Debit_Louly

SNIM_FormationCaptee

SNIM_Litho

SNIM_PE_Louly

SNIM_SuiviPiezo_Louly

U_Carte_Topo200

U_Quadrant_Topo200

U_TableFields

U_TableRelation
Pump test information?

Numerolrh, DateEssai, Pailer, Debit, Duree, NieveauDynamiqueDescente, DurreRemontee,

NiveauDynamiqueRemontee

Primary table with primary key for relating to other tables.

$\mathrm{Z}$ metre, Methode foration utilisation explosif, nature captage, prof premiere venue, prof demiere venue, repere mesure, observation, formation lithologique, profondeur toit, profondeur mur, nature aquifere, type aquifere, aquifere, stratigraphie, nom nappe, coupe saisie, bibliographie, ajout hc, consolider, a verifer, date instruction, date maj

\section{Nocomment}

Well identifier, $\mathrm{x}, \mathrm{y}, \mathrm{z}$ (elevation), coordinates, formation name

ID, forage, $X, Y, Z$, Prof du toit, formation

Well identifier, drill intervales, lithologies over intervals

ID, Nom de Forage, Toit, Mur, Lithologie

Drilling information including total depth, and ESRI decimal degree coordinates

id, code_PE, nom,PE, Z_SNIM, propretare, Longitude, Latitude, Xcoord, Ycoord, MAPINFO_ID

Time series measurements for wells (years); operator

id_charge_hydro, Nom_PE, Date_mesure, mesure, operateur

cities, ..

No comment

No comment

No comment 


\section{Appendix C}

Hydrogeologic Inventory Based on Existing Reports 
Table 11. Hydrogeologic inventory of aquifer area, thickness, and volume.

$\left[\mathrm{km}^{2}=\right.$ square kilometers $; \mathrm{m}=$ meter; $\mathrm{m}^{3}=$ cubic meters $]$

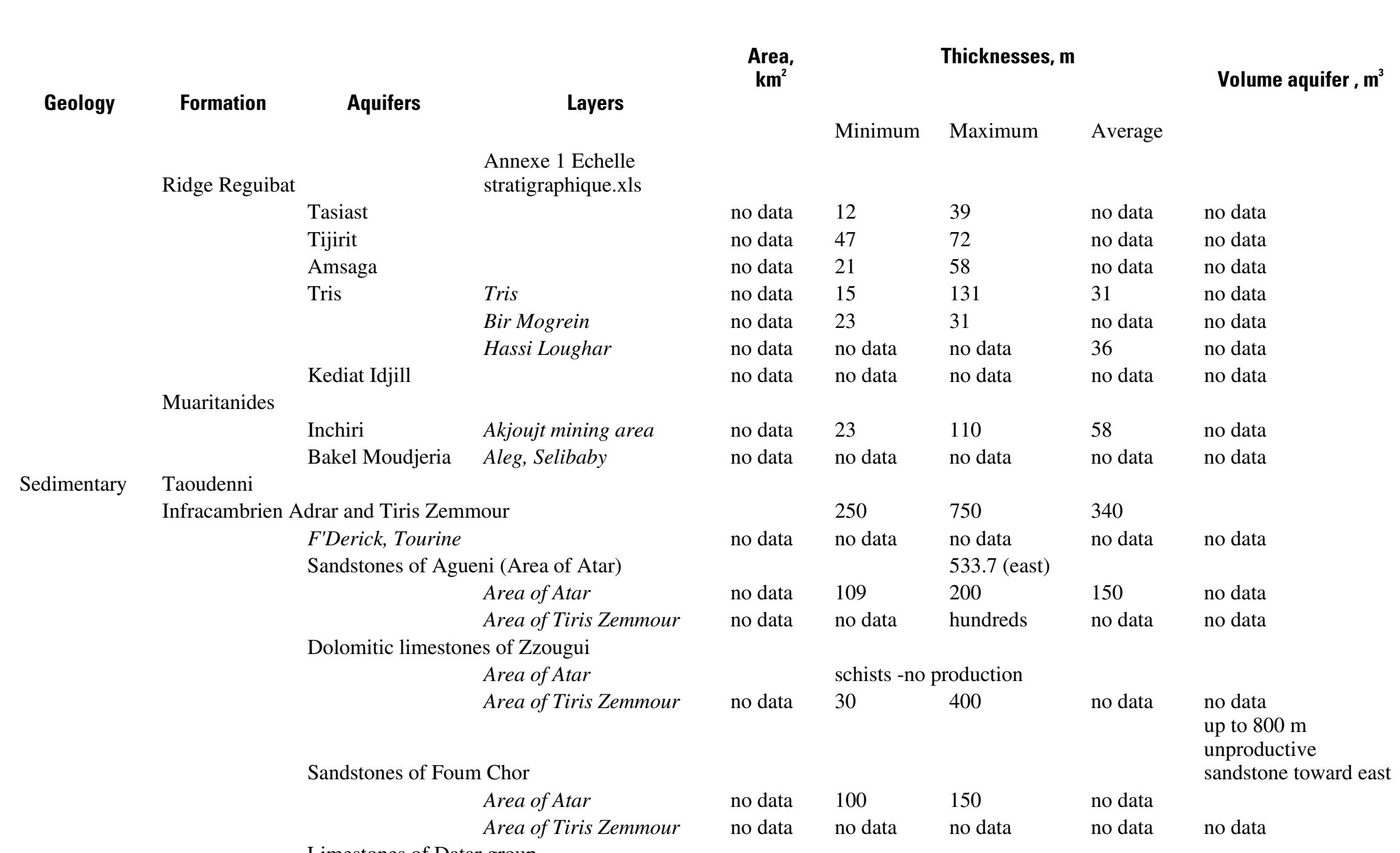




$\begin{array}{llllll}\text { Area of Atar } & \text { no data } & \text { no data } & \text { no data } & \text { no data } & \text { no data } \\ \text { Limestones of Atar } & \text { no data } & \text { no data } & \text { no data } & 173 & \text { no data } \\ \text { Limestones of Tawaz } & \text { no data } & 36 & 54 & \text { no data } & \text { no data }\end{array}$

Area of Tiris Zemmour

no data

Limestones of

Touiderguilt

no data

24

68

no data

22

138

no data

no data Infracambrien (Assaba, Hodh, Gharbi)

Massive sandstones of disturbed

$$
\text { Area Kankossa }
$$

no data

400

no data

no data

no data

Sandstones with stratifications (ss of Aioun)

Cambrian

$$
\text { Area Kiffa }
$$

no data $\quad 80$

no data 35

no data

\section{Lower tillite}

Sandstones of Dar Teleb and El Aguer

Higher tillite

Cambrian-Ordovician

Pilites and japers in Adrar

$$
\text { Area El Mreiti, Atar }
$$

no data

50

1000

no data

no data

Pilites and japers in Adrar

Area Kiffa, Kankossa, Nema, Djigueni

Sandstones with patinachamois

$$
\text { Area Assaba }
$$

Cambrian-Ordovician

$$
\text { Higher dolomite }
$$

Cambrian-Ordovician

Sandstones of Tagant and Assaba

Diorite and dolerite intrusions

\begin{tabular}{|c|c|c|c|c|}
\hline no data & no data & 200 & no data & no data \\
\hline no data & no data & no data & no data & no data \\
\hline no data & no data & 100 & no data & no data \\
\hline no data & no data & no data & no data & no data \\
\hline no data & no data & no data & no data & no data \\
\hline no data & no data & no data & no data & no data \\
\hline no data & 234 & & 1492 & top \\
\hline no data & 522 & & & top \\
\hline no data & 550 & & & top \\
\hline no data & 1726 & & & top \\
\hline
\end{tabular}

\section{Devonian}

Sedimentary formations in Taoudenni syncline

Devonian
Silurian
Cambrian-Ordovician
Precambrian

Aquifers discontinuous; southern edge of Tindouf syncline

Black Zmmour 


\begin{tabular}{|c|c|c|c|c|c|c|}
\hline & $\begin{array}{l}\text { Area Bir Moghrein } \\
\text { Area Yetin north }\end{array}$ & $\begin{array}{l}\text { no data } \\
\text { no data }\end{array}$ & $\begin{array}{l}\text { no data } \\
\text { no data }\end{array}$ & $\begin{array}{l}\text { no data } \\
\text { no data }\end{array}$ & $\begin{array}{l}\text { no data } \\
\text { no data }\end{array}$ & $\begin{array}{l}\text { no data } \\
\text { no data }\end{array}$ \\
\hline \multicolumn{7}{|c|}{ Aquifer continuous Continental Guide (Jurassic) } \\
\hline \multicolumn{7}{|c|}{ Under Dahr de Nema } \\
\hline Under dunes & $\begin{array}{l}\text { Areas Nema, Suina, } \\
\text { Djigueni, Bassikonou } \\
\text { El Mreve and Adhafer }\end{array}$ & $\begin{array}{l}16,760 \\
\text { no data } \\
\text { no data }\end{array}$ & $\begin{array}{l}\text { no data } \\
\text { no data } \\
\text { no data }\end{array}$ & $\begin{array}{l}\text { no data } \\
\text { no data } \\
\text { no data }\end{array}$ & $\begin{array}{l}\text { no data } \\
\text { no data } \\
\text { no data }\end{array}$ & $\begin{array}{l}\text { no data } \\
\text { no data } \\
\text { no data }\end{array}$ \\
\hline \multicolumn{7}{|c|}{ Aquifer continuous deep Maestrichtien } \\
\hline & Areas Aleg, Rosso, Nouakchott, Nouadhibou & no data & no data & no data & no data & no data \\
\hline \multicolumn{7}{|l|}{ Coastal mining areas } \\
\hline Trarza & $\begin{array}{l}\text { Cretaceous (Masetrichtien) } \\
\text { Eocene } \\
\text { Continental Terminal } \\
\text { Idini well field production - subphreatic layer }\end{array}$ & $\begin{array}{l}\text { no data } \\
\text { no data } \\
\text { no data }\end{array}$ & $\begin{array}{l}\text { no data } \\
\text { no data } \\
30\end{array}$ & $\begin{array}{l}\text { no data } \\
\text { no data } \\
300\end{array}$ & $\begin{array}{l}\text { no data } \\
\text { no data } \\
\text { east, west }\end{array}$ & $\begin{array}{l}\text { no data } \\
\text { no data } \\
\text { no data }\end{array}$ \\
\hline $\begin{array}{l}\text { Bennichab } \\
\text { Tiersioum }\end{array}$ & & $\begin{array}{l}\text { no data } \\
\text { no data }\end{array}$ & $\begin{array}{l}\text { no data } \\
\text { no data }\end{array}$ & $\begin{array}{l}\text { no data } \\
\text { no data }\end{array}$ & $\begin{array}{l}\text { no data } \\
\text { no data }\end{array}$ & $\begin{array}{l}\text { no data } \\
\text { no data }\end{array}$ \\
\hline \multicolumn{6}{|l|}{ Continuous recent sedimentary } & \\
\hline Adrar, Mau & zides, Tagant, Assaba, Guidimaka, Hodhs & no data & 2 & 26 & 10 & no data \\
\hline Alluviam of & legal River & no data & no data & 35 & 15 & no data \\
\hline Dunes & & no data & 10 & 100 & no data & no data \\
\hline Quaternary & sand dunes, wadi sands & no data & 10 & 30 & no data & no data \\
\hline
\end{tabular}


Table 12. Hydrogeologic inventory of aquifer production, porosity, and hit ratio.

$\left[\mathrm{m}=\right.$ meter $; \%=$ percent $; \mathrm{m}^{3}=$ cubic meters $]$

\begin{tabular}{|c|c|c|c|c|c|c|c|c|c|c|c|}
\hline \multirow[b]{2}{*}{ Geology } & \multirow[b]{2}{*}{ Formation } & \multirow[b]{2}{*}{ Aquifers } & \multirow[b]{2}{*}{ Layers } & \multicolumn{3}{|c|}{$\begin{array}{c}\text { Productive zone, } \\
\text { m }\end{array}$} & \multirow[t]{2}{*}{$\begin{array}{c}\text { Porosity, } \\
\%\end{array}$} & \multirow[t]{2}{*}{$\begin{array}{c}\text { Volume } \\
\text { water } \\
\text { x10 } \mathrm{m}^{3}\end{array}$} & \multirow[b]{2}{*}{ minimum } & \multirow{2}{*}{$\begin{array}{c}\text { Hit Ratio, } \\
\% \\
\text { maximum }\end{array}$} & \multirow[b]{2}{*}{ average } \\
\hline & & & & minimum & maximum & average & & & & & \\
\hline \multicolumn{12}{|l|}{ Base } \\
\hline & Ridge Reguiba & & $\begin{array}{l}\text { Annexe } 1 \text { Echelle } \\
\text { stratigraphique.xls }\end{array}$ & & & & & & & & \\
\hline & & Tasiast & & no data & no data & no data & no data & no data & no data & no data & no data \\
\hline & & Tijirit & & no data & no data & no data & no data & no data & no data & no data & no data \\
\hline & & Amsaga & & no data & no data & no data & no data & no data & no data & no data & 21 \\
\hline & & Tris & Tris & no data & no data & no data & no data & no data & no data & no data & no data \\
\hline & & & Bir Mogrein & no data & no data & no data & no data & no data & no data & no data & no data \\
\hline & & & Hassi Loughar & no data & no data & no data & no data & no data & no data & no data & no data \\
\hline & & Kediat Idjill & & no data & no data & no data & no data & no data & no data & no data & no data \\
\hline & Muaritanides & & & & & & & & & & \\
\hline & & Inchiri & Akjoujt mining area & no data & no data & no data & no data & no data & 38 & 50 & no data \\
\hline & & Bakel Moudjeria & Aleg, Selibaby & no data & no data & no data & no data & no data & 34 & 62 & no data \\
\hline \multirow[t]{12}{*}{ Sedimentary } & Taoudenni & & & & & & & & & & \\
\hline & Infracambrien & Idrar and Tiris Zem & & & & & & & & & \\
\hline & & $F^{\prime}$ Derick, Tourine & & no data & no data & no data & no data & no data & no data & no data & no data \\
\hline & & Sandstones of Ag & (Area of Atar) & & & & & & & & \\
\hline & & & Area of Atar & no data & no data & no data & no data & no data & no data & 58 & no data \\
\hline & & & Area of Tiris Zemmour & no data & no data & no data & no data & no data & no data & 50 & no data \\
\hline & & Dolomitic limesto & of Zzougui & & & & & & & & \\
\hline & & & Area of Atar & na & na & na & na & na & na & na & na \\
\hline & & & Area of Tiris Zemmour & no data & no data & no data & no data & no data & no data & no data & 70 \\
\hline & & Sandstones of Fou & Chor & & & & & & & & \\
\hline & & & Area of Atar & & & & no data & no data & 55 & 88 & no data \\
\hline & & & Area of Tiris Zemmour & no data & no data & no data & no data & no data & no data & no data & 50 \\
\hline
\end{tabular}




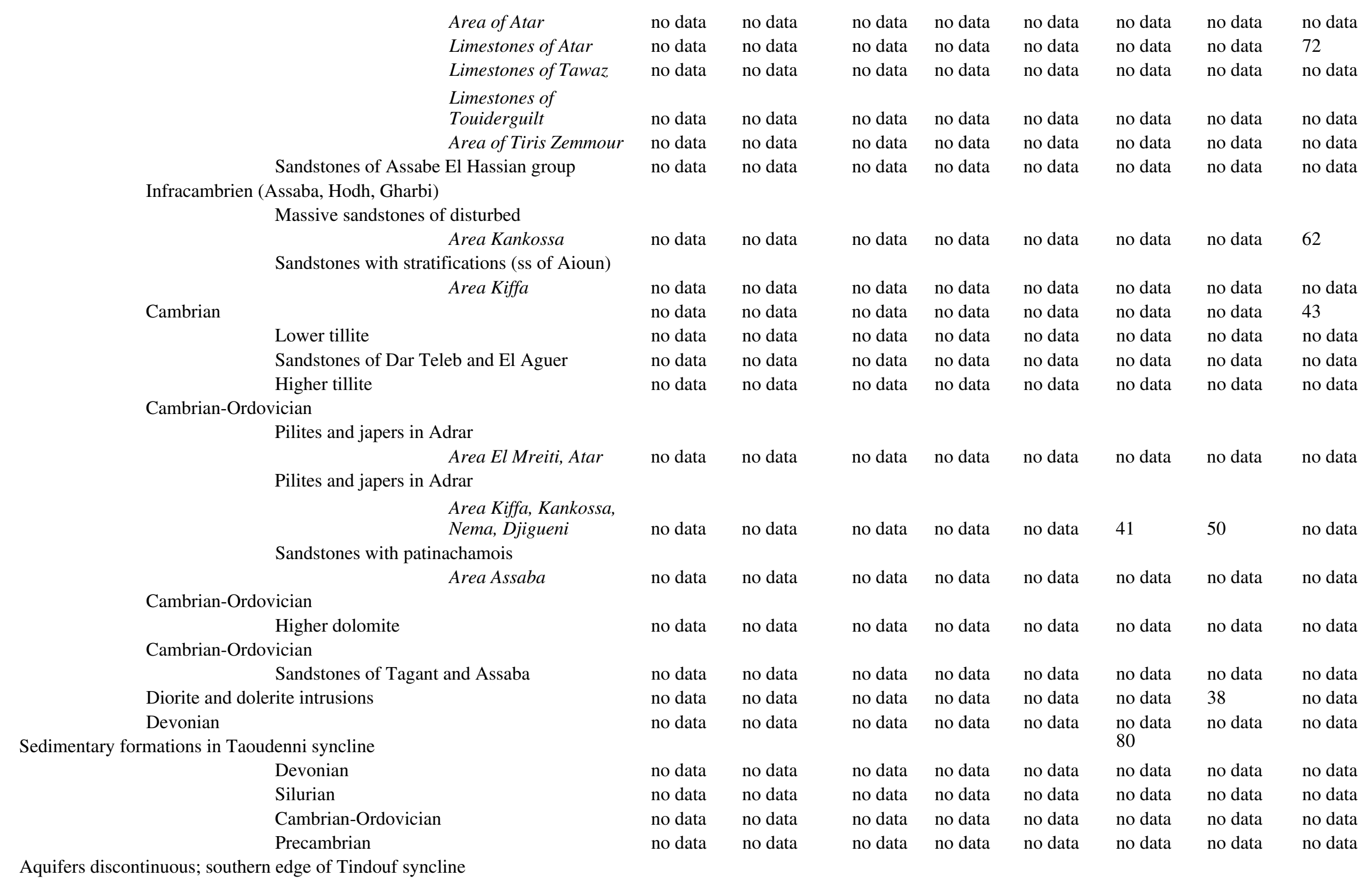




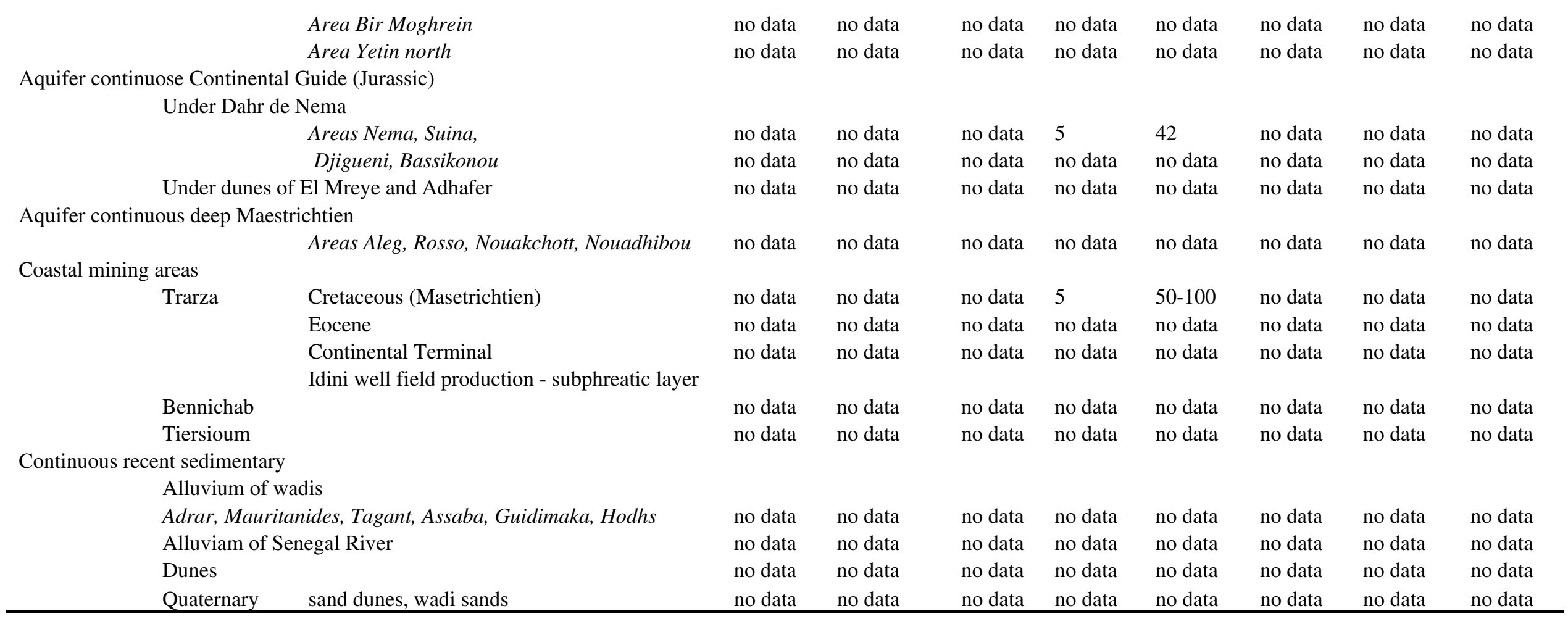


Table 13. Hydrogeologic inventory of aquifer instantaneous flows and associated salinity concentrations.

$\left[\mathrm{m}^{3} \mathrm{hr}^{-1}=\right.$ cubic meters per hour; $\mathrm{g} \mathrm{l}^{-1}=$ grams per liter $]$

\begin{tabular}{|c|c|c|c|c|c|c|c|c|c|c|}
\hline \multirow[b]{2}{*}{ Geology } & \multirow[b]{2}{*}{ Formation } & \multirow[b]{2}{*}{ Aquifers } & \multirow[b]{2}{*}{ Layers } & \multirow[b]{2}{*}{ Average } & \multicolumn{2}{|c|}{$\begin{array}{c}\text { Instantaneous Flows } \\
\qquad \mathbf{m}^{3} \mathbf{h r}^{-1}\end{array}$} & \multirow[b]{2}{*}{ Average } & \multicolumn{2}{|c|}{$\begin{array}{l}\text { Salinity } \\
\mathrm{g} \mathrm{l}^{-1}\end{array}$} & \multirow[b]{2}{*}{ Average } \\
\hline & & & & & Minimum & Maximum & & Minimum & Maximum & \\
\hline \multicolumn{11}{|l|}{ Base } \\
\hline & Ridge Reguibat & & $\begin{array}{l}\text { Annexe } 1 \text { Echelle } \\
\text { stratigraphique.xls }\end{array}$ & & & & & & & \\
\hline & & Tasiast & & no data & 0.6 & 3 & no data & 3 & 37 & no data \\
\hline & & Tijirit & & no data & no data & no data & no data & no data & no data & no data \\
\hline & & Amsaga & & 21 & no data & no data & no data & no data & no data & no data \\
\hline & & Tris & Tris & no data & 8 & 20 & no data & 5 & 60 & no data \\
\hline & & & Bir Mogrein & no data & 1 & 3 & no data & 2.2 & 2.5 & no data \\
\hline & & & Hassi Loughar & no data & 3.3 & no data & no data & 0.5 & 1.6 & no data \\
\hline & & Kediat Idjill & & no data & no data & no data & no data & 0.3 & 1 & 0.45 \\
\hline & Muaritanides & & & & & & & & & \\
\hline & & Inchiri & Akjoujt mining area & no data & 1 & 30 & 5 & 1 & no data & no data \\
\hline & & Bakel Moudjeria & Aleg, Selibaby & no data & 2.5 & 8.6 & 2.5 & no data & 1 & no data \\
\hline \multirow[t]{11}{*}{ Sedimentary } & Taoudenni & & & & & & & & & \\
\hline & Infracambrien & Adrar and Tiris Zen & & & & & & & & \\
\hline & & F'Derick, Tourine & & no data & no data & no data & no data & no data & no data & no data \\
\hline & & Sandstones of $\mathrm{Ag}$ & (Area of Atar) & & & & & & & \\
\hline & & & Area of Atar & no data & 10 & 80 & no data & 0.15 & 1.7 & no data \\
\hline & & & Area of Tiris Zemmour & no data & 0.5 & 2 & 1.2 & 2 & 5 & no data \\
\hline & & Dolomitic limesto & of Zzougui & & & & & & & \\
\hline & & & Area of Atar & no data & no data & no data & no data & no data & no data & no data \\
\hline & & & Area of Tiris Zemmour & 70 & 0.6 & 5 & 2.3 & 2 & 25 & 7 \\
\hline & & Sandstones of Fol & hor & & & & & & & \\
\hline & & & Area of Atar & no data & 1 & 50 & no data & 0.5 & 8.4 & no data \\
\hline
\end{tabular}




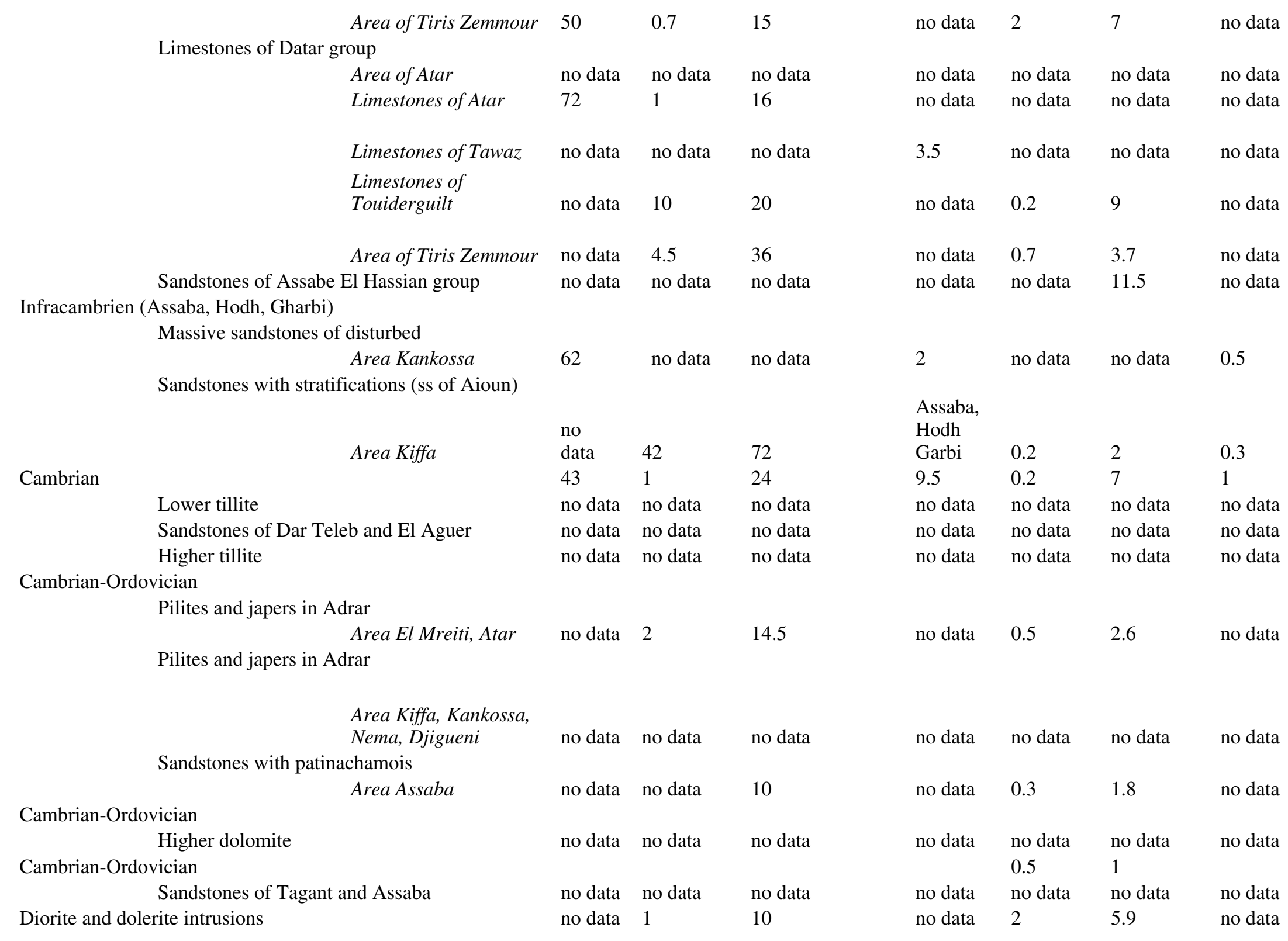


Devonian

Sedimentary formations in Taoudenni syncline

Devonian

Silurian

\section{Cambrian-Ordovician}

Precambrian

Aquifers discontinouous; southern edge of Tindouf syncline

Black Zmmour

$$
\begin{aligned}
& \text { Area Bir Moghrein } \\
& \text { Area Yetin north }
\end{aligned}
$$

Aquifer continuose Continental Guide (Jurassic)

Under Dahr de Nema

$$
\begin{aligned}
& \text { Areas Nema, Suina, } \\
& \text { Djigueni, Bassikonou }
\end{aligned}
$$

Under dunes of El Mreye and Adhafer

Aquifer continuous deep Maestrichtien

$$
\text { Areas Aleg, Rosso, Nouakchott, Nouadhibou }
$$

\section{Coastal mining areas}

Trarza

Bennichab

Tiersioum

Continuous recent sedimentary

\section{Cretaceous (Masetrichtien)}

\section{Eocene}

Continental Terminal

Idini well field production - subphreatic layer

Alluvium of wadis

Adrar, Mauritanides, Tagant, Assaba, Guidimaka, Hodhs

Alluviam of Senegal River

Dunes

Quaternary

$\begin{array}{lll}\text { no data } & \text { no data } & \text { no data } \\ \text { no data } & \text { no data } & \text { no data } \\ \text { no data } & \text { no data } & \text { no data } \\ \text { no data } & \text { no data } & \text { no data } \\ \text { no data } & \text { no data } & \text { no data }\end{array}$

no data no data

no data no data

no data

no data

no data no data

no data no data

no data no data

no data

no data

no data

no data no data

no data

no data no data

no data 30

no data 10

$$
\begin{aligned}
& 10 \\
& 25
\end{aligned}
$$

no data no data

no data no data

no data no data

no data no data

no data no data

no data no data

\section{no data}

60

30

80

no data

no data no data

no data

no data

no data no data

no data

no data

no data

no data

no data

no data

no data

no data

no data

no data

no data

no data

no data

no data

no data

1

no data

no dat

0.5

0.5

0.01

no data

no data

no data

no data

no data

east, west 
Table 14. Hydrogeologic inventory of aquifer hydraulic properties.

$\left[\mathrm{m}^{2} \mathrm{~s}^{-1}=\right.$ square meters per second $; \mathrm{m}^{3} \mathrm{~d}^{-1}=$ cubic meters per day]

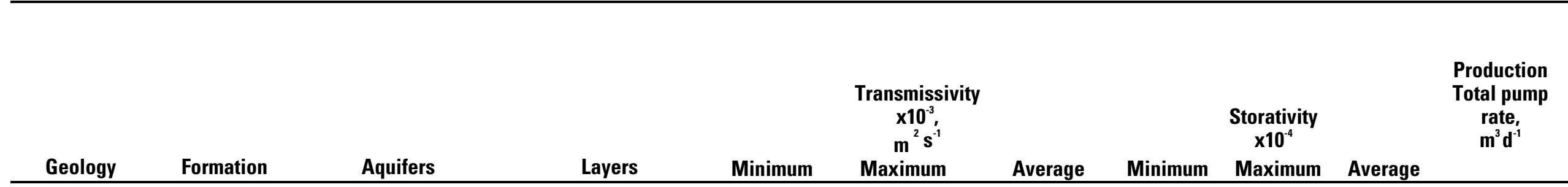

Base

Ridge Reguibat

Tasiast
Tijirit
Amsaga

Tris

Kediat Idjill

Muaritanides

$\begin{array}{ll}\text { Inchiri } & \text { Akjoujt mining area } \\ \text { Bakel Moudjeria } & \text { Aleg, Selibaby }\end{array}$

Sedimentary

stratigraphique.xls

Taoudenni
Annexe 1 Echelle

$\begin{array}{ll}\text { no data } & \text { no data } \\ \text { no data } & \text { no data } \\ \text { no data } & \text { no data } \\ \text { no data } & \text { no data } \\ \text { no data } & \text { no data } \\ \text { no data } & \text { no data } \\ \text { no data } & \text { no data }\end{array}$

$2.5 \quad 6$

no data no data

Infracambrien Adrar and Tiris Zemmour

F'Derick, Tourine

Sandstones of Agueni (Area of Atar)

$$
\text { Area of Atar }
$$

no data

no data

Area of Tiris Zemmour

0.2

Dolomitic limestones of Zzougui

Area of Atar
0.8

no data no data

no data

no data

no data

no data

no data

1

no data

$\begin{array}{ll}\text { no data } & \text { no data } \\ \text { no data } & \text { no data } \\ \text { no data } & \text { no data } \\ \text { no data } & \text { no data } \\ \text { no data } & \text { no data } \\ \text { no data } & \text { no data } \\ \text { no data } & \text { no data }\end{array}$

no data

no data

no data

no data

no data

no data

no data

no data

no data

no data

no data

no data

no data

no data

\section{no data no data}

no data

no data

4.5

no data

no data

1.5

no data

no data

no data no data

0.5

no data

no data

no data

no data

no data 


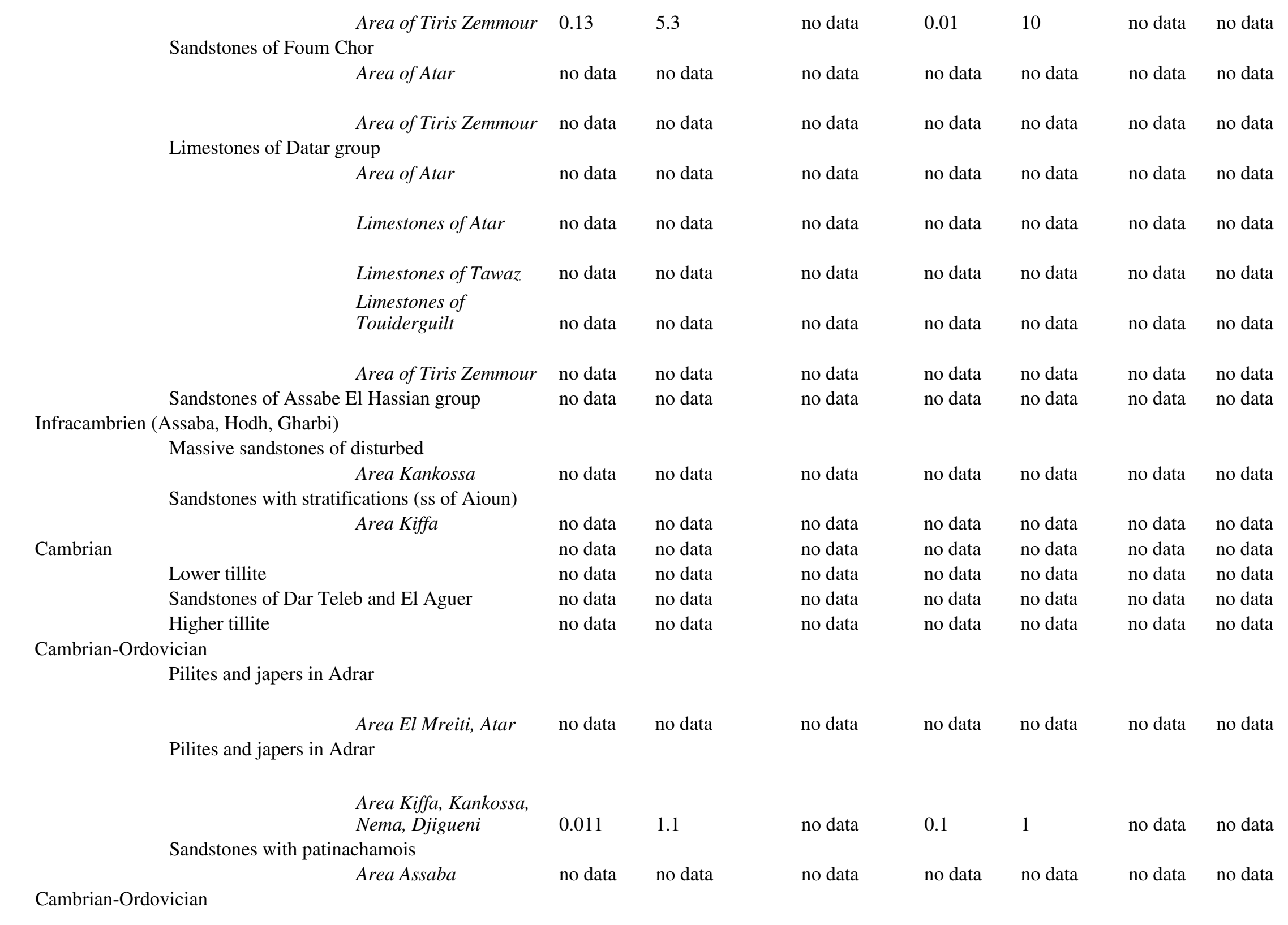




$$
\text { Higher dolomite }
$$

Sandstones of Tagant and Assaba

Diorite and dolerite intrusions

Devonian

Sedimentary formations in Taoudenni syncline

Devonian
Silurian
Cambrian-Ordovician
Precambrian

Precambrian

Aquifers discontinouous; southern edge of Tindouf syncline

Black Zmmour

$$
\begin{aligned}
& \text { Area Bir Moghrein } \\
& \text { Area Yetin north }
\end{aligned}
$$

Aquifer continuose Continental Guide (Jurassic)

Under Dahr de Nema

$$
\begin{aligned}
& \text { Areas Nema, Suina, } \\
& \text { Djigueni, Bassikonou }
\end{aligned}
$$

Under dunes of El Mreye and Adhafer

Aquifer continuous deep Maestrichtien

Coastal mining areas

$$
\text { Areas Aleg, Rosso, Nouakchott, Nouadhibou }
$$

Trarza

Cretaceous (Masetrichtien)
Eocene
Continental Terminal
Idini well field production - subphreatic layer

Bennichab

Tiersioum

nt sedimentary

Alluvium of wadis

Adrar, Mauritanides, Tagant, Assaba, Guidimaka, Hodhs

Alluvium of Senegal River

Dunes

Quaternary no data

no data

no data

no data

no data

no data

no data

no data

no data

no data

no data

no data

no data

no data

no data

no data

no data

no data

0.1

1

3.1

no data

no data

2.1

no data

no data

no data

no data

9

no data

no data

2.1

no data

no data

no data

no data no data

no data

no data

no data

no data

no data

no data

no data

no data

no data

no data

no data

no data

west, east

no data

subphreatic

no data

no data

no data no data

no data

no data

no data no data

no data

no data

no data

no data no data

no data

no data

no data

no data

no data

no data

no data

no data

no data

no data

no data

no data

no data

no data

no data

no data

no data

no data

no data

no data

no data

no data

no data

no data

no data

no data

no data

no data

no data

no data

no data

no data

no data

no data

no data

no data

no data

no data

no data

no data

no data

no data

no data

no data

no data

no data

no data no data

no data

no data

no data

no data

no data

no data

50000

no data 750

no data no data

no data no data

no data

no data

no data

no data

no data

no data

no data

no data

no data

no data

no data

no data

no data

no data

no data 
Table 15. Hydrogeologic inventory of aquifer piezometric head map and recharge potential.

$\left[\mathrm{km}^{2}=\right.$ square kilometers; $\%=$ percent $]$

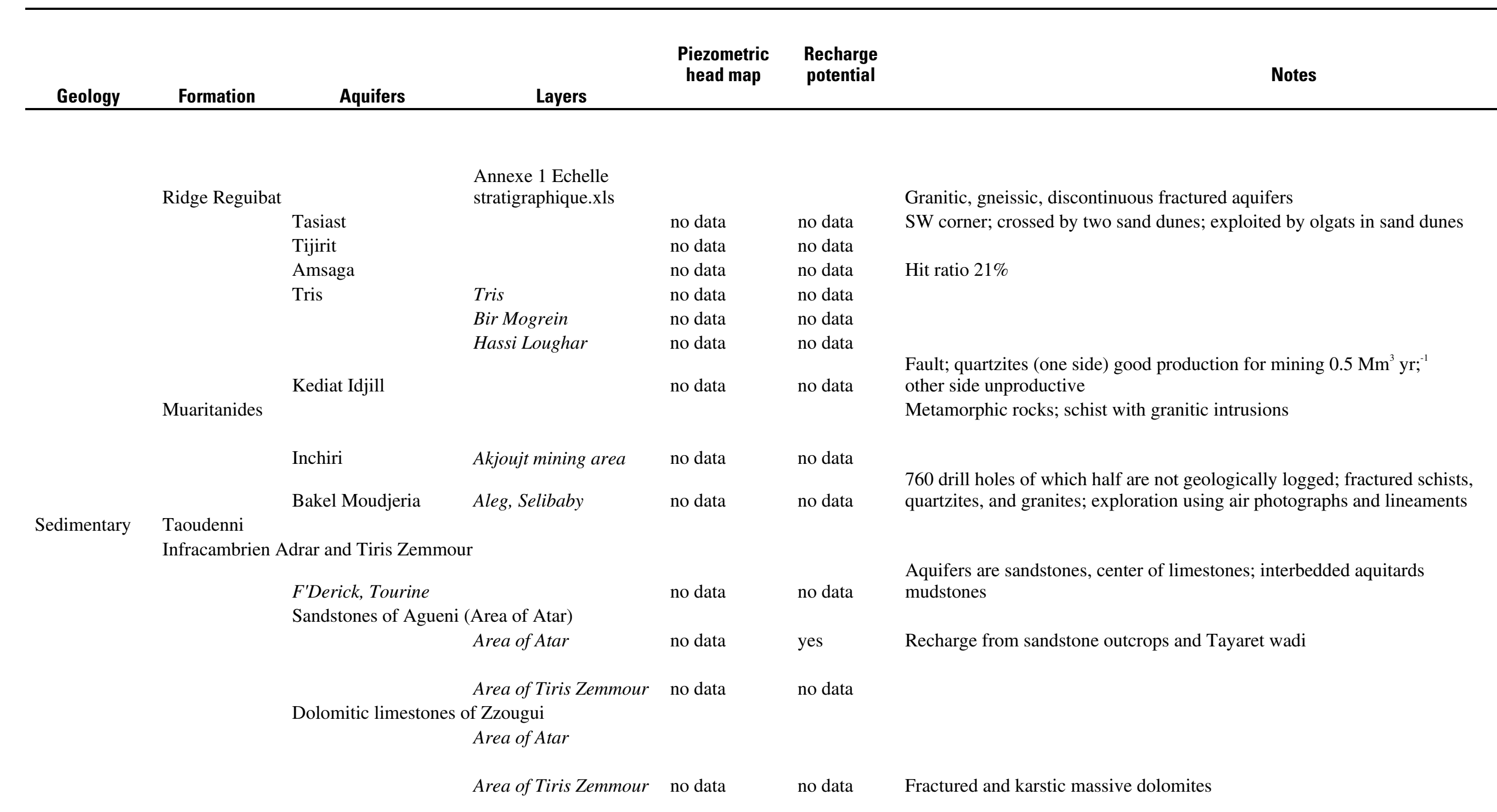


Sandstones of Foum Chor

Limestones of Datar group

$$
\begin{aligned}
& \text { Area of Atar } \\
& \text { Area of Tiris Zemmour }
\end{aligned}
$$

no data

no data

Area of Atar

Limestones of Atar

Limestones of Tawaz

Limestones of

Touiderguilt

Area of Tiris Zemmour

Sandstones of Assabe El Hassian group

Infracambrien (Assaba, Hodh, Gharbi)

Massive sandstones of disturbed

$$
\text { Area Kankossa }
$$

Sandstones with stratifications (ss of Aioun)

$$
\text { Area Kiffa }
$$

\section{Cambrian}

\section{Lower tillite}

Sandstones of Dar Teleb and El Aguer

Higher tillite

\section{Cambrian-Ordovician}

Pilites and japers in Adrar

Pilites and japers in Adrar

$$
\text { Area El Mreiti, Atar }
$$

no data

Area Kiffa, Kankossa,

Nema, Djigueni

no data

no data

Sandstones with patinachamois

\section{no data}

no data

yes

yes

no data

no data

no data

no data

yes

no data

no data

no data

no data

no data

Cambrian-Ordovician

$$
\text { Area Assaba }
$$

no data

Area Assaba no data yes

Recharge in near surface fractures may be associated with Tariofet and Amber (assumed poor) wadis

Recharge by dune Oum Arouaba (320 km²); limited fractures, poor aquifer

East of Turine, limestones under unproductive sandstone-clay $44 \mathrm{~m}$; drilling sites based on Direct Current electrical surveys

Small anticlinal structure is primary region of flow; piezometric head follows topography

Siliceous rocks; fractures N70, N170, N110 devoid of primary porosity) Recharge from streambed infiltration. Piezometric head: pelites (low waters), May-July, 1986; (high waters), October-November, 1986. east-west gradient, $3.5 \times 10-3$, north-south gradient, $1.5 \times 10-3$

Recharged by overlying dunes

Appendix 2 
Higher dolomite

\section{Cambrian-Ordovician}

Sandstones of Tagant and Assaba

Diorite and dolerite intrusions

Devonian

Sedimentary formations in Taoudenni syncline

\section{Devonian}

Silurian

Cambrian-Ordovician

Precambrian

Aquifers discontinouous; southern edge of Tindouf syncline

Black Zmmour

$$
\begin{aligned}
& \text { Area Bir Moghrein } \\
& \text { Area Yetin north }
\end{aligned}
$$

Aquifer continuose Continental Guide (Jurassic)

Under Dahr de Nema

\section{Areas Nema, Suina,}

Dijueni, Bassikonou

Under dunes of El Mreye and Adhafer

Aquifer continuous deep Maestrichtien

Areas Aleg, Rosso, Nouakchott, Nouadhibou

Cretaceous (Masetrichtien)
Eocene
Continental Terminal

Continental Terminal

Bennichab

Idini well field production - subphreatic layer

Tiersioum

Continuous recent sedimentary

Alluvium of wadis

Adrar, Mauritanides, Tagant, Assaba, Guidimaka, Hodhs

Alluviam of Senegal River

Dunes

Quaternary

sand dunes, wadi sands no data

no data

no data

no data

yesdata

no data

no data

no data

no data

no data

yes

no data

no data

yes

no data

no data

no data

yes

yes

no data

no data

no data

no data

no data no data

no data

no data

no data

no data

no data

no data

no data

no data

no data

no data

no data

no data

no data

no data

no data

no data

no data

no data

no data

no data

no data

no data
Recharged by wadis oeud El Abiod, Tidjikja, and Tamourt; many fractures - appendix 2

Between Adrar and Tagant; in unpopulated areas; no drilling

Piezometric head 50-80 m $(2001,1974-75,1963)$

Piezometric head map

Piezometric head 1961 (preproduction); production after 1969; time series; piezometric head map; decrease $2.5-5.5 \mathrm{~m} / 13 \mathrm{yrs}(0.2-0.4 \mathrm{~m} / \mathrm{yr})$

Piezometric head map; decrease $1-1.3 \mathrm{~m} / 30 \mathrm{yrs}$ ( .. ); salt water interface

Recharged by rain; lowest in salinity; seasonal storage (?)

Recharged by rain; lowest in salinity; seasonal storage (?)

Resource potential unknown; fossil water? 


\section{Appendix D}

Meteorology Questionnaire 


\section{SPREADSHEET - Meteorology Questionnaire}

Instructions: Fill out questionnaires to the best of your ability. Feel free to make copies and send to other persons that may contribute relevant information. Return completed questionnaires to Christopher Wnuk, Constella Futures International, One Thomas Circle, NW, Suite 200, Washington DC, 20005, 703-715-0847, cwnuk@resourcesfordevelopment.com [ROW 1$]$

Date: [ROW 2 ]

Institution: [ ROW 3 ]

Contact Information: $\quad$ ROW 4$]$

\section{[ COLUMNs shown below ]}

CODE for this measurement station [ COLUMN A ]

Owner ID [ COLUMN B ]

\section{Basin Information}

Basin identifier (name) [ COLUMN C $]$

Basin measurement station (type): outlet, other [COLUMN D]

Basin location: coordinates of centroid [COLUMN E]

\section{Measurements}

Location of measurements, e.g. E 2 [COLUMN F $]$

Location of measurements, e.g. $\mathrm{N} 4{ }_{-}^{\circ}$ [ COLUMN G]

\section{Precipitation}

Gage type, e.g., tipping bucket, other [ COLUMN H ]

Type of measurement, e.g. rainfall, snowfall, both [ COLUMN I ]

Frequency of precipitation measurements, e.g. 15-minutes, 1-hour, daily, other [COLUMN J]

Period of record, e.g. 1925-1955, 1956-present [ COLUMN K ] 
Describe data format(s): web, digital (excel, access, other), paper [ COLUMN L ]

Contact information of person or place and cost to obtain these data [COLUMN M $]$

\section{Evaporation}

Frequency of evaporation measurements, e.g. 15-minutes, 1-hour, daily, other [ COLUMN N]

Type of measurement, pan, other [ COLUMN O]

Period of record, e.g. 1925-1955, 1956-present [ COLUMN P ]

Describe data format(s): web, digital (excel, access, other), paper [ COLUMN Q ]

Contact information of person or place and cost to obtain these data [COLUMN R $]$

\section{Potential Evapotranspiration}

Frequency of potential evapotranspiration measurements, e.g. 15-minutes, 1-hour, daily, other $\quad$ [COLUMN S ] Type of measurement [ COLUMN T ]

Period of record, e.g. 1925-1955, 1956-present [COLUMN U \

Describe data format(s): web, digital (excel, access, other), paper [ COLUMN V]

Contact information of person or place and cost to obtain these data [COLUMN W]

\section{Relative Humidity}

Frequency of humidity measurements, e.g. 15-minutes, 1-hour, daily, other [ COLUMN X ]

Type of measurement [ COLUMN Y]

Period of record, e.g. 1925-1955, 1956-present [ COLUMN Z ]

Describe data format(s): web, digital (excel, access, other), paper [ COLUMN AA $]$

Contact information of person or place and cost to obtain these data [ COLUMN AB

\section{Temperatures}

Frequency of temperature measurements, e.g. 15-minutes, 1-hour, daily, other

\section{[ COLUMN AC]}

Type of measurement, e.g. minimum, maximum, average, others [COLUMN AD ]

Period of record, e.g. 1925-1955, 1956-present [COLUMN AE] 
Describe data format(s): web, digital (excel, access, other), paper [ COLUMN AF ]

Contact information of person or place and cost to obtain these data [COLUMN AG]

\section{Precipitation-Quality Monitoring}

Physical parameters measured, e.g. pH, dissolved oxygen, conductivity, redox potential, temperature [ COLUMN AH ]

Type of study: synoptic (one time) or temporal (many times) [ COLUMN AI]

Quality assurance: yes, no, not sure [COLUMN AJ]

Describe data format(s): web, digital (excel, access, other), paper [ COLUMN AK ]

Contact information of person or place and cost to obtain these data [COLUMN AL]

Water-quality sampled, e.g. major ions, trace elements, pesticides, isotopes or environmental tracers [COLUMN AM ]

Quality assurance: yes, no [COLUMN AN

Describe data format(s): web, digital (excel, access, other), paper [ COLUMN AO ]

Contact information of person or place and cost to obtain these data [ COLUMN AP ] 


\section{Appendix E}

Hydrology Questionnaire 


\section{SPREADSHEET - Hydrology Questionnaire}

Instructions: Fill out questionnaires to the best of your ability. Feel free to make copies and send to other persons that may contribute relevant information. Return completed questionnaires to Christopher Wnuk, Constella Futures International, One Thomas Circle, NW, Suite 200, Washington DC, 20005, 703-715-0847, cwnuk@resourcesfordevelopment.com [ROW 1$]$

\section{Date: [ROW 2 ]}

Institution: [ ROW 3 ]

Contact Information: $\quad$ ROW 4$]$

\section{[ COLUMNs shown below ]}

CODE for this measurement station [ COLUMN A ]

Owner ID [ COLUMN B $]$

\section{Basin Information}

Basin identifier (name) [ COLUMN C ]

Basin measurement station (type): outlet, other [COLUMN D]

Basin location: coordinates of centroid [ COLUMN E]

\section{Measurements}

Location of measurements, e.g. E 2, COLUMN F ]

Location of measurements, e.g. $\mathrm{N} 4{ }^{\circ}$ " [ COLUMN G]

\section{Streamflow Discharge I}

Type of measurement, e.g. direct, indirect other [ COLUMN H $]$

Gage type, e.g., crest stage, velocity meter, pressure transducer, other [ COLUMN I ]

Frequency of measurements, e.g. 15-minutes, 1-hour, daily, other [ COLUMN J]

Period of record available, e.g. 1925-1955, 1956-present [ COLUMN K ]

Year of study [ COLUMN L $]$ 
Average annual discharge, in cubic metes per second [ COLUMN M $]$

Standard deviation of annual streamflow discharge, in cubic metes per second [COLUMN N]

Minimum annual streamflow discharge (baseflow), in cubic metes per second [COLUMN O ]

Maximum annual streamflow discharge (peakflow), in cubic metes per second [COLUMN P ]

Baseflow index [ COLUMN Q]

Describe data format(s): web, digital (excel, access, other), paper [ COLUMN R ]

Contact information of person or place and cost to obtain these data [COLUMN S ]

\section{Streamflow Water Quality}

Physical parameters measured, e.g. pH, dissolved oxygen, conductivity, redox potential, temperature [COLUMN T]

Type of study: synoptic (one time) or temporal (many times) [COLUMN U]

Type of probe used; e.g. YSI, Hydrolab,, other, not sure [ COLUMN V]

Quality assurance: yes, no, not sure [ COLUMN W]

Describe available data format(s): web, digital (excel, access, other), paper [COLUMN X ]

Contact information of person or place and cost to obtain these data [COLUMN Y ]

Water-quality sampled, e.g. major ions, trace elements, pesticides, isotopes or environmental tracers associated with water or bed sediment; suspended sediment [ COLUMN Z ]

Quality assurance: yes, no [ COLUMN AA ]

Describe available data format(s): web, digital (excel, access, other), paper [COLUMN AB ]

Contact information of person or place and cost to obtain these data [ COLUMN AC ]

Aquatic biology sampled: algae, macroinvertebrates, fish [COLUMN AD $]$

Quality assurance: yes, no [ COLUMN AE ]

Describe data format(s): web, digital (excel, access, other), paper [ COLUMN AF ]

Contact information of person or place and cost to obtain these data [COLUMN AG

\section{Return Flow Discharge}

Type of measurement, e.g. direct, indirect other [ COLUMN AH $]$

Gage type, e.g., crest stage, velocity meter, pressure transducer, other [COLUMN AI ]

Frequency of measurements, e.g. 15-minutes, 1-hour, daily, other [COLUMN AJ] 
Period of record, e.g. 1925-1955, 1956-present [ COLUMN AK ]

Year of study [ COLUMN AL ]

Average annual return flow, in cubic metes per second [ COLUMN AM $]$

Standard deviation of annual return flow, in cubic metes per second [ COLUMN AN]

Minimum annual return flow (baseflow), in cubic metes per second [ COLUMN AO ]

Maximum annual return flow (peakflow), in cubic metes per second [ COLUMN AP ]

Estimate total number return flow (point) sources in basin [COLUMN AQ

Describe data format(s): web, digital (excel, access, other), paper [ COLUMN AR $]$

Contact information of person or place and cost to obtain these data [COLUMN AS ]

\section{Return Flow Water Quality}

Physical parameters measured, e.g. pH, dissolved oxygen, conductivity, redox potential, temperature [COLUMN AT

Type of study: synoptic (one time) or temporal (many times) [COLUMN AU]

Type of probe used; e.g. YSI, Hydrolab,, other, not sure [ COLUMN AV]

Quality assurance: yes, no, not sure [ COLUMN A W

Describe data format(s): web, digital (excel, access, other), paper [ COLUMN AX $]$

Contact information of person or place and cost to obtain these data [COLUMN AY]

Water-quality sampled, e.g. major ions, trace elements, pesticides, isotopes or environmental tracers associated with water or bed sediment; suspended sediment [ COLUMN AZ ]

Quality assurance: yes, no [ COLUMN BA ]

Describe data format(s): web, digital (excel, access, other), paper [ COLUMN BB $]$

Contact information of person or place and cost to obtain these data [COLUMN BC $]$

\section{Withdrawal Flow Discharge}

Type of measurement, e.g. direct, indirect other [ COLUMN BD]

Gage type, e.g., crest stage, velocity meter, pressure transducer, other [COLUMN BE $]$

Frequency of measurements, e.g. 15-minutes, 1-hour, daily, other [COLUMN BF ]

Period of record, e.g. 1925-1955, 1956-present [ COLUMN BG ]

Year of study [ COLUMN BH ]

Average annual withdrawal flow discharge, in cubic metes per second $[$ COLUMN BI 
Standard deviation of annual withdrawal flow, in cubic metes per second [COLUMN BJ]

Minimum annual withdrawal flow (baseflow), in cubic metes per second [COLUMN BK ]

Maximum annual withdrawal flow (peakflow), in cubic metes per second [COLUMN BL ]

Estimate total number return flow (point) sources in basin [COLUMN BM ]

Describe data format(s): web, digital (excel, access, other), paper [ COLUMN BN]

Contact information of person or place and cost to obtain these data [COLUMN BO]

\section{Withdrawal Flow Water Quality}

Physical parameters measured, e.g. pH, dissolved oxygen, conductivity, redox potential, temperature [COLUMN BP ]

Type of study: synoptic (one time) or temporal (many times) [COLUMN BQ]

Type of probe used; e.g. YSI, Hydrolab,, other, not sure [ COLUMN BR $]$

Quality assurance: yes, no, not sure [COLUMN BS ]

Describe data format(s): web, digital (excel, access, other), paper [ COLUMN BT ]

Contact information of person or place and cost to obtain these data [COLUMN BU]

Water-quality sampled, e.g. major ions, trace elements, pesticides, isotopes or environmental tracers associated with water or bed sediment; suspended sediment [ COLUMN BV]

Quality assurance: yes, no [COLUMN BW]

Describe data format(s): web, digital (excel, access, other), paper [ COLUMN BX ]

Contact information of person or place and cost to obtain these data [ COLUMN BY] 


\section{Appendix F}

Groundwater Questionnaire 


\section{SPREADSHEET - Groundwater Questionnaire}

Instructions: Fill out questionnaires to the best of your ability. Feel free to make copies and send to other persons that may contribute relevant information. Return completed questionnaires to Christopher Wnuk, Constella Futures International, One Thomas Circle, NW, Suite 200, Washington DC, 20005, 703-715-0847, cwnuk@resourcesfordevelopment.com [ROW 1$]$

Date: [ ROW 2]

Institution: [ ROW 3 ]

Contact Information: [ ROW 4$]$

\section{[ COLUMNs shown below ]}

CODE for this borehole [ COLUMN A $]$

Owner ID [ COLUMN B ]

\section{Borehole Information}

Borehole or well identifier (name) [ COLUMN C ]

Location borehole or well, e.g. E2_o___ $"$ [ COLUMN D]

Location borehole or well, e.g. $\mathrm{N} 4$ _o " [ COLUMN E]

Drilling method, e.g. rotary wash, flight augur, hollow stem, hand, other [COLUMN F ]

\section{Well Construction Information}

Construction date, e.g. 1/1/1999 [COLUMN G ]

Land surface altitude, in meters above sea level [COLUMN H]

Well depth, in meters below land surface [COLUMN I]

Casing top, in meters below land surface [COLUMN J]

Casing bottom, in meters below land surface [COLUMN K ]

Casing length, in meters [COLUMN L ]

Casing diameter, in centimeters [COLUMN M $]$

Screen top, in meters below land surface [COLUMN N]

Screen bottom, in meters below land surface [COLUMN O] 
Screen length, in meters [COLUMN P]

Screen type, e.g. slotted, perforated, other [COLUMN Q ]

Gravel pack around screen; e.g. yes, no [COLUMN R ]

Bentonite (clay) above gravel pack, e.g. yes, no [COLUMN S ]

Development method, e.g. pumped at 3 borehole volumes and until physical parameters stabilized [COLUMN T]

Contact information of person or place and cost to obtain these data [COLUMN U]

\section{Pump Test Information}

Depth of pump, in meters below surface [COLUMN V]

Type of pump, e.g. [COLUMN W]

Discharge (constant), in cubic meters per second [COLUMN X $]$

Pumping duration, in hours [COLUMN Y ]

Water level (initial in pumping well), in meters below land surface [COLUMN Z

Water level (final in pumping well), in meters below land surface [COLUMN AA ]

Drawdown (in well), in meters [COLUMN AB ]

Location observation well 1, e.g. E 2 $"$ [COLUMN AC $]$

Location observation well 1, e.g. $\mathrm{N} 4{ }^{\circ} \_$[C___ [COLUMN AD]

Water level (initial in observation well 1), in meters below land surface [COLUMN AE

Water level (final in observation well 1), in meters below land surface [COLUMN AF

Location observation well 2 , e.g. E $2{ }^{\circ}$ " [COLUMN AG $\rceil$

Location observation well 2 , e.g. $\mathrm{N} 4{ }_{-}^{\circ}$ "_ $"$ [COLUMN AH ]

Water level (initial in observation well 2), in meters below land surface $[$ COLUMN AI Water level (final in observation well 2), in meters below land surface [COLUMN AJ] Describe data format(s): web, digital (excel, access, other), paper [COLUMN AK ] Contact information of person or place and cost to obtain these data [COLUMN AL]

\section{Water Level Monitoring}

Date static water level measured [COLUMN AM ]

Water level (static), in meters below land surface [COLUMN AN $]$ 
Describe relative accuracy of measurement [COLUMN AO ]

Describe quality assurance of measurement [COLUMN AP ]

List name of domestic or industrial pumping centers [COLUMN AO]

Location of pumping well(s) in same aquifer; e.g. E 2

" [COLUMN AR

Location of pumping well(s) in same aquifer; e.g. $\mathrm{N} 4$ " [COLUMN AS ]

Describe data format(s): web, digital (excel, access, other), paper [COLUMN AT $]$

Contact information of person or place and cost to obtain these data [COLUMN AU]

\section{Water-Quality Monitoring}

Sample depth, in meters below surface [COLUMN A V ]

Sample date or period, e.g. 1/1/1920 or 10/02/2000-09/31/2004 [COLUMN AW]

Physical parameter measured: $\mathrm{pH}$ [COLUMN AX]

Physical parameters measured: dissolved oxygen, in milligrams per liter [COLUMN AY ]

Physical parameters measured: conductivity, in microSiemens per centimeter [COLUMN AZ]

Physical parameters measured: redox potential (Eh), in millivolts [COLUMN BA

Physical parameters measured: temperature, in degrees Celsius $[\mathrm{COLUMN} \mathrm{BB]}$

Type of study: synoptic (one time) or temporal (many times) [COLUMN BC]

Type of probe used; e.g. YSI, Hydrolab, other, not sure [COLUMN BD]

Quality assurance: yes, no, not sure [COLUMN BE]

Describe data format(s): web, digital (excel, access, other), paper [COLUMN BF ]

Contact information of person or place and cost to obtain these data [COLUMN BG ]

Water-quality sampled for major ions: yes, no, not sure [COLUMN BH]

Water-quality sampled for trace elements: yes, no, not sure [COLUMN BI]

Water-quality sampled for pesticides: yes, no, not sure [COLUMN BJ]

Water-quality sampled for isotopes: yes, no, not sure [COLUMN BK]

Water-quality sampled for environmental tracers: yes, no, not sure $[\mathrm{COLUMN} \mathrm{BL}$

Water-quality sampled for dissolved organic carbon: yes, no, not sure [COLUMN BM]

Water-quality sampled for radiogenic compounds: yes, no, not sure [COLUMN BN]

Quality assurance: yes, no [COLUMN BO] 
Describe data format(s): web, digital (excel, access, other), paper [COLUMN BP ]

Contact information of person or place and cost to obtain these data [COLUMN BQ]

\section{Aquifer Information}

Depth interval, in meters beginning and meters ending below surface [COLUMN BR ]

Age of formation [COLUMN BS ]

Stratigraphic unit name: formation and group [COLUMN BT ]

Lithologic description: clay, sand, silt, gravel, or bedrock [COLUMN BU]

Hydrostratigraphic description: aquifer or aquitard [COLUMN BV]

Thickness of lithologies in the open screened interval, in meters [COLUMN BW]

Thickness of aquifer-like material over entire depth of well, in meters [COLUMN BX]

Thickness of aquifer-like material in the open screened interval, in meters [COLUMN BY]

Provide contact information of person or place and cost to obtain these data [COLUMN BZ

Specific capacity, in liter per second per meter [COLUMN CA ]

Hydraulic conductivity, in meter per day [COLUMN CB]

Depth of hydraulic conductivity measurement, in meters below surface [COLUMN CC]

Transmissivity, in meter squared per day [COLUMN CD]

Depth interval over which transmissivity value pertains, in meters beginning and meters ending below surface [COLUMN CE]

Describe data format(s): web, digital (excel, access, other), paper [COLUMN CF ]

Contact information of person or place and cost to obtain these data [COLUMN CG ]

\section{Geophysical Borehole Logging}

Date well logged [COLUMN CH ]

Electric logging: yes, no, unsure [COLUMN CI]

Induction logging: yes, no, unsure [COLUMN CJ]

Gamma logging: yes, no, unsure [COLUMN CK ]

Neutron logging: yes, no, unsure [COLUMN CL]

Contact information of person or place and cost to obtain these data [COLUMN CM $]$ 


\section{Area Surface Geophysics}

Date surface geophysical surveys conducted [COLUMN CN] Seismic reflection survey: yes, no, unsure [COLUMN CO] Seismic refraction survey: yes, no, unsure [COLUMN CP ] Seismic tomographic survey: yes, no, unsure [COLUMN CQ] Ground gravity survey: yes, no, unsure [COLUMN CR ] Airborne electromagnetic survey: yes, no, unsure [COLUMN CS $]$ Ground electromagnetic survey: yes, no, unsure [COLUMN CT ] Airborne electromagnetic survey: yes, no, unsure [COLUMN CU Ground magnetotelluric survey: yes, no, unsure [COLUMN CV] Ground resistivity survey: yes, no, unsure [COLUMN CW $]$ Seismic tomographic survey: yes, no, unsure [COLUMN CX ] Time-domain electromagnetic survey: yes, no, unsure [COLUMN CY ]

Contact information of person or place and cost to obtain these data [COLUMN CZ ] 